\title{
Docking, synthesis, and NMR studies of mannosyl trisaccharide ligands for DC-SIGN lectin $\uparrow$
}

\author{
José J. Reina, ${ }^{a}$ Irene Díaz, ${ }^{a}$ Pedro M. Nieto, ${ }^{* a}$ Nuria E. Campillo, ${ }^{b}$ Juan A. Páez, ${ }^{b}$ Georges Tabarani, ${ }^{c}$ \\ Franck Fieschi ${ }^{c}$ and Javier Rojo ${ }^{* a}$
}

\author{
Received 6th February 2008, Accepted 28th April 2008 \\ First published as an Advance Article on the web 5th June 2008 \\ DOI: 10.1039/b802144a
}

DC-SIGN, a lectin, which presents at the surface of immature dendritic cells, constitutes nowadays a promising target for the design of new antiviral drugs. This lectin recognizes highly glycosylated proteins present at the surface of several pathogens such as HIV, Ebola virus, Candida albicans, Mycobacterium tuberculosis, etc. Understanding the binding mode of this lectin is a topic of tremendous interest and will permit a rational design of new and more selective ligands. Here, we present computational and experimental tools to study the interaction of di- and trisaccharides with DC-SIGN. Docking analysis of complexes involving mannosyl di- and trisaccharides and the carbohydrate recognition domain (CRD) of DC-SIGN have been performed. Trisaccharides Mana1,2[Mana1,6]Man 1 and

Mana1,3[Mana1,6]Man 2 were synthesized from an orthogonally protected mannose as a common intermediate. Using these ligands and the soluble extracellular domain (ECD) of DC-SIGN, NMR experiments based on STD and transfer-NOE were performed providing additional information. Conformational analysis of the mannosyl ligands in the free and bound states was done. These studies have demonstrated that terminal mannoses at positions 2 or 3 in the trisaccharides are the most important moiety and present the strongest contact with the binding site of the lectin. Multiple binding modes could be proposed and therefore should be considered in the design of new ligands.

\section{Introduction}

DC-SIGN (dendritic cell-specific ICAM-3 grabbing non-integrin) or CD209 is a C-type lectin expressed at the surface of immature dendritic cells. This lectin presents at the C-terminus a carbohydrate recognition domain (CRD) able to interact with highly glycosylated proteins found on several pathogens such as viruses (HIV-1 and 2, SIV-1, Ebola virus, HCV, SARS virus, cytomegalovirus, dengue virus); bacteria (Helicobacter pylori, Klebsiella pneumonae, Mycobacterium tuberculosis); yeast (Candida albicans); and parasites (Schistosoma mansoni, Leishmania pifanoi). ${ }^{1,2}$ This so broad spectrum of pathogens recognized by DC-SIGN has led to consider this lectin as an universal pathogen receptor. This lectin has attracted the interest of the scientific community since the discovery of the role that DC-SIGN plays in a HIV trans infection process. ${ }^{3}$

Pathogen glycoproteins recognized by DC-SIGN contain mainly mannose and fucose carbohydrate structures as $N$ glycans at different Asn positions of the glycoproteins. High mannose structure, constituted by $\mathrm{Man}_{9} \mathrm{GlcNAc}_{2}$ as the main

${ }^{a}$ Grupo de Carbohidratos, Instituto de Investigaciones Qu'imicas, CSIC Universidad de Sevilla, Américo Vespucio 49, 41092 Seville, Spain. E-mail: javier.rojo@iiq.csic.es; pedro.nieto@iiq.csic.es; Fax: +34954 4605 65

'Instituto de Química Médica, CSIC, Juan de la Cierva 3, 20006 Madrid, Spain

'Laboratoire des Protéines Membranaires, Université Joseph Fourier/CEA, DSV/CNRS, UMR 5075, Institut de Biologie Structurale Jean-Pierre Ebel, 41, rue Jules Horowitz, 38027 Grenoble, Cedex 1, France

$\dagger$ Electronic supplementary information (ESI) available: Further details of docking and NMR studies. See DOI: 10.1039/b802144a epitope, is considered one of the strongest ligands for this lectin. Carbohydrate-protein interactions are selective, most of the time calcium dependent, and very weak. Nature overcomes this weak affinity providing a multivalent presentation of carbohydrate epitopes such as cluster organization at the cell surface of glycosphingolipids and highly glycosylated glycoproteins. To study and intervene in biological processes where this type of interaction is involved, the design and preparation of multivalent carbohydrate systems is required. There is a continuing interest in designing new and effective multivalent tools. Selection of carbohydrate epitopes requires a deep knowledge of the binding mode of the ligands and the binding site of the protein receptor. Information about binding constants of monovalent and multivalent mannosyl and fucosyl oligosaccharides with DC-SIGN have been reported by different groups using a variety of techniques such as ELLA, biosensors, etc. ${ }^{4-11}$ However, to date only scarce information at the molecular level is available about how carbohydrates are recognized by DCSIGN in solution. To our best knowledge, the only available information concerning carbohydrate ligands and DC-SIGN is at the solid state.X-Ray structures of complexes formed by different carbohydrate oligosaccharides with up to 9 units constituting part of the high mannose structure and CRD of DC- and L-SIGN have been recently published. ${ }^{12-14}$ Our interest on the receptor DCSIGN lead us to explore in more detail the molecular basis of this recognition process with the aim todesignand prepareappropriate ligands and their corresponding multivalent systems for potential applications in biological processes where DC-SIGN is involved. Also, availablestructural information about the binding process of carbohydrates to DC-SIGN indicates the possibility of different binding modes of these ligands. A preliminary study involving 
DC-SIGN and carbohydrate mimics has been published recently by some of us. ${ }^{15}$

Here, we describe the use of computational (docking studies) and NMR (STD, and transfer NOE experiments) tools to get information about the binding mode of DC-SIGN ligands. Among the potential epitopes to be tested as ligands for DC-SIGN, we have analyzed two mannosyl trisaccharides. On one hand, these compounds represent a good choice as binding ligands (better than the simple mannose) and on the other hand, they can be obtained with a reasonable synthetic cost. Because the high mannose structure consists of mannose units alinked by glycosidic bonds at positions 2, 3, and 6, we have selected two branched trisaccharides. The trisaccharide Mana1,2[Mana1,6]Man 1 and the trisaccharide Mana1,3[Mana1,6] Man 2. The trisaccharide $\mathbf{1}$ is not present in the high mannose structure, but it constitutes the repeated unit of the cell-wall mannans such as lipoarabinomannan (LAM) present in Mycobacterium tuberculosis which is recognized by DC-SIGN. ${ }^{16-19}$ The trisaccharide 2 is a fragment present in the high mannose responsible for the recognition process by DCSIGN as has been described previously. ${ }^{12}$

As a starting point for docking studies, we have used the crystallographic information already published. We have analyzed five selected ligands, the two trisaccharides above mentioned and the corresponding disaccharide moieties present in these molecules: Mana1,2Man, Mana1,3Man, and Mana1,6Man. Simultaneously, we have synthesized the two selected trisaccharides with a short linker at the anomeric position which will allow the attachment of these ligands to multivalent scaffolds afterwards. We have used an orthogonally protected mannose previously described as a common intermediate for the synthesis of the trisaccharides. ${ }^{20}$ These mannosyl oligosaccharides have been used to test their binding behavior in the presence of the soluble extra-cellular domain (ECD) of DC-SIGN. The analysis of the binding process in solution has been performed using a series of NMR experiments directed to obtain structural data of the bound ligands.

\section{Results and discussion}

\section{Docking analysis}

To gain insight about the binding mode of DC-SIGN ligands, a docking study was carried out considering a representative set of mannosyl di- and trisaccharide structures. In particular, we selected for these computational studies the disaccharides Mana1,2Man, Mana1,3Man and Mana1,6Man, and the trisaccharides Mana1,3[Mana1,6]Man and Mana1,2[Mana1,6]Man. (Fig. 1)

The docking of the proposed ligands into the DC-SIGN binding site was done using an automated docking procedure (FlexiDock) using the crystal structure data of the complex of DC-SIGN and the pentasaccharide $\mathrm{GlcNAc}_{2} \mathrm{Man}_{3}$ (pdb code $1 \mathrm{k} 9 \mathrm{i}$ ). Those structures showing key distances or torsional angles inconsistent with experimental results were rejected. Then, the best solutions in terms of energy were energy-minimized prior to further analysis. The final complexes were evaluated in terms of consensus of ligand-protein interactions and dihedral angles with the experimental data and the known values of energy interaction using the programs STC and DOCK module (SYBYL) (Table 1). Detailed information including key protein residues involved in the binding,
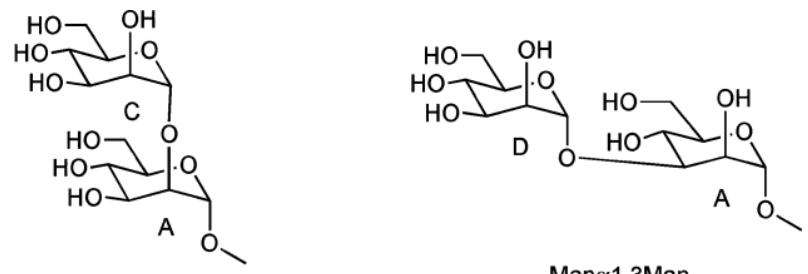

Man 1,3 Man

Man 1 1,2Man

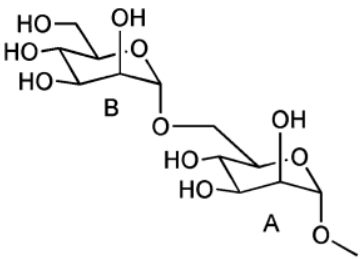

Man 1,6 Man

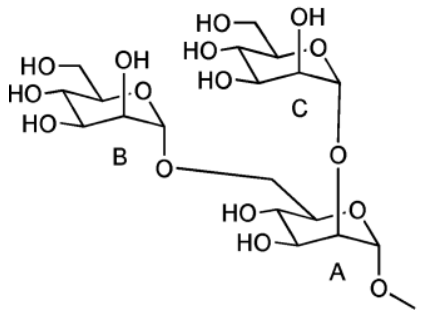

Man 1,2[Man 1,6]Man

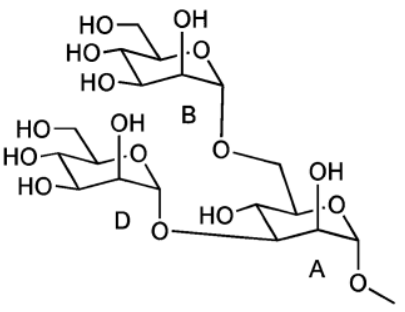

Man $1,3[$ Man $\alpha 1,6]$ Man
Fig. 1 Chemical structures of the three disaccharides (Mana1,2Man, Mana1,3Man and Mana1,6Man), and the two trisaccharides (Mana1,3[Mana1,6]Man and Mana1,2[Mana1,6]Man) considered in the docking studies.

the $U / w$ conformational space, along with the distance to the $\mathrm{Ca}^{2+}$ (primary binding site) and the interprotonic distances are given in the supplementary information (Table S1 and Fig. S1-S20).

Based on the crystal structure, it is possible to define two possible binding sites for disaccharides: a primary one containing the $\mathrm{Ca}^{2+}$ atom and an adjacent secondary one. We performed docking studies considering two possible sites for the a1-2 and a1-6-linked mannoses. In both cases, the most favoured binding mode (Table 1) is located at the primary site, presenting interactions with the $\mathrm{Ca}^{2+}$ atom; therefore, we focused on the binding at the primary site in subsequent studies.

The docking study of Mana1,2Man led to three families of structures with two different binding modes (see supplementary information, Fig. S5-S8). In the less populated orientation (cluster 3 ) the reducing end side is bound to the $\mathrm{Ca}^{2+}$ ion at the primary binding site. The major orientation, where the non-reducing end of the disaccharide binds the $\mathrm{Ca}^{2+}$ atom (cluster 1 and cluster 2), corresponds to the best solution in terms of energy and geometry restrictions. It should be mentioned that recent crystallographic analysis of the complex formed by this disaccharide and DC-SIGN has shown multiple binding modes which have been postulated as a mechanism for increasing affinity. ${ }^{14}$ All acceptable structures found for Mana1,6Man are mixtures of $\mathrm{gg}$ and gt conformers around the $x$ torsion angle (see supplementary information, 
Table 1 Dihedral angles and docking energy

\begin{tabular}{lllr}
\hline Complex & $U / w$ & $\mathrm{D} G_{\text {bind }} / \mathrm{kcal} \mathrm{mol}^{-1}$ & $E_{\mathrm{dock}} / \mathrm{kcal} \mathrm{mol}^{-1}$ \\
\hline $1 \mathrm{~d} 13$ & $1 \rightarrow 3: 65.2 / 144.8$ & -4.8 & 2.1 \\
$1 \mathrm{~d} 16$ & $1 \rightarrow 6: 63.8 / 153.0$ & -5.3 & -34.6 \\
$2 \mathrm{~d} 16$ & $1 \rightarrow 6: 52.2 / 166.0$ & -2.2 & -0.1 \\
$1 \mathrm{~d} 12$ & $1 \rightarrow 2: 68.5 / 85.9$ & -5.9 & -37.2 \\
$2 \mathrm{~d} 12$ & $1 \rightarrow 2: 42.1 / 90.3$ & -5.6 & -19.6 \\
$1 \mathrm{t} 36$ & $1 \rightarrow 3: 96.5 / 155.16 \leftarrow 1: 68.7 / 181.4$ & -7.3 & -55.0 \\
$1 \mathrm{t} 26$ & $1 \rightarrow 2: 81.4 / 168.06 \leftarrow 1: 88.4 / 205.6$ & -6.7 & -51.4 \\
\hline
\end{tabular}

Fig. S9-S11), although after energy-minimization the gg conformation (1d16) was found to be the most stable one (Fig. S12). The non-reducing end of the sugar chain binds to the $\mathrm{Ca}^{2+}$ atom in all the best solutions. The docking studies of Mana1,3Man yielded three possible families (see supplementary information, Fig. S1S4). The most populated binding mode, which also had the best values of docking energy and $\mathrm{D} G_{\text {bind }}$, showed in all the solutions the non-reducing end of the sugar bounded to the $\mathrm{Ca}^{2+}$ atom (with a distance of the $\mathrm{O} 3$ atom to the calcium atom around $2.3 \AA$ ) and glycosidic linkage torsions in accordance with the experimental angle ranges data for the linkage $1,3+49<U<82$ and-16 $<$ $w<32$ ) (Fig. S1).

The complexes are stabilized by a large number of hydrogen bonds, which in the case of the disaccharide Mana1,3Man, were experimentally observed in the complex of DC-SIGN and the pentasaccharide $\mathrm{GlcNAc}_{2} \mathrm{Man}_{3}$ (see Table S1). ${ }^{12}$ In addition to these interactions, the $\mathrm{Ca}^{2+}$ ion is bound by the equatorial 3- and 4-hydroxyl groups of a mannose residue (see Table S1). A detailed description of relevant protein-ligand interactions, including $\mathrm{C}-$ $\mathrm{H}$-aromatic, is given in the supplementary information. The $\mathrm{D} G_{\text {bind }}$ and the docking energy calculated with the STC and DOCK program respectively, suggest that the disaccharides with a1-2 and a1-6 type union are the best ligands for DC-SIGN (Table 1). These results are in agreement with the experimental values of binding published by Weis et al. ${ }^{\mathbf{2}}$

In the case of the trisaccharides, the FlexiDock analysis of the complex of Mana1,3[Mana1,6]Man with DC-SIGN led to a model that is very similar to that of the crystal structure (Fig. S13S17). The a-1,2 linkage in Mana1,2[Mana1,6]Man is described by an ensemble of exo-anomeric conformers ( $U$ between-30 and $\left.60^{\circ}\right)$ compatible with the experimental data. The short distances between $\mathrm{H} 1 \mathrm{c}$ and $\mathrm{H} 2 \mathrm{a}$, and between $\mathrm{H} 1 \mathrm{c}$ and $\mathrm{H} 1 \mathrm{a}$ observed for Mana1,2[Mana1,6]Man are in agreement with the NMR studies of this linkage (see supplementary information, Fig. S18-S22). The 1,6-glycosyl bonding in the trimannoside was found exclusively as gt conformers around the $x$ torsion, in contrast to the mixture of $\mathrm{gg}$ and $\mathrm{gt}$ conformers obtained for the 1,6-bonded structures of the dimannoside. The structural parameters of the final complex of each trisaccharide and the energy of interaction are gathered in Table S1. The hydrogen bond network observed for the disaccharides is preserved in both trisaccharide-complex models (Table S1). Both trisaccharides showed hydrophobic interaction between the ManC (1t26) and ManD (1t36) units and the residue Val 351. Aromatic interactions of both complexes with Phe 313 have also been found. In addition, the mannose ManA in Mana1,2[Mana1,6]Man complex displays a C-H $\cdots$ aromatic interaction $\left(a_{\mathrm{ch} x}=160.2, d_{\mathrm{CX}}(\AA)=4.0, d_{\mathrm{HpX}}\right.$ $(\AA)=1.2)$.

\section{Ligand synthesis}

The trisaccharides $\operatorname{Mana}(1 \rightarrow 3)[\mathrm{Mana}(1 \rightarrow 6)] \mathrm{Mana} \mathrm{OCH}_{2} \mathrm{CH}_{2}-$ $\mathrm{NH}_{2} 2$ and Mana(1 2)[Mana(1 6)] Mana1OCH $\mathrm{CH}_{2} \mathrm{NH}_{2} \mathbf{1}$ have been prepared using an orthogonally protected mannose derivative $\mathbf{8}$ as a common intermediate. This mannose derivative $\mathbf{8}$ was prepared in 7 steps from 2-azidoethyl a-D-mannopyranoside (3) as shown in Scheme 1.20

In a previous communication we have described the synthesis of compound $\mathbf{8}$ and the corresponding orthogonal deprotections at positions 2, 3 and $6 .{ }^{20}$ The hydroxyl group at position 6 was protected as a silyl group using tert-butyldiphenylsilyl chloride (TBDPSCl) and imidazole in DMF. A benzyl group was introduced at position 4 as a permanent protecting group (this position will not be glycosylated in this synthetic approach) using benzyl chloride and sodium hydride in DMF in $79 \%$ yield. For this aim, the formation of an acetonide using $2,2^{\mathbf{j}}$-dimethoxypropane and pyridinium $p$-toluenesulfonate (PPTS) in acetone was first necessary to protect positions 2 and 3 simultaneously. After introducing the benzyl group at position 4, the acetonide was easily cleavage with TFA in dichloromethane at rt to give compound 5 in $63 \%$ yield over three steps. The hydroxyl group at position 3 was selectively protected as the $p$-methoxybenzyl (PMB) ether using a stannylene acetal intermediate as strategy. Reaction with dibutyltin oxide in toluene at reflux and then, $\mathrm{PMBCl}$ and tetrabutylammonium iodide (TBAI) gave a complete regioselective protection of that position giving compound $\mathbf{6}$ in good yield. Finally, a levulinoyl ester was used to protect position 2 using levulinic acid and dicyclohexylcarbodiimide (DCC) in dichloromethane at $\mathrm{rt}$ affording the orthogonally protected mannose $\mathbf{8}$ in $88 \%$ yield.

Synthesis of trimannose $\mathbf{2}$ was accomplished using the mannose derivative $\mathbf{1 0}$ as central unit with free hydroxyl groups at positions 3 and 6 (Scheme 2). This mannose 10 was prepared from orthogonally protected mannose 8 in two steps by cleavage of silyl group at position 6 with TBAF in THF at rt to afford mannose derivative 9 and following treatment with TFA at $20{ }^{\circ} \mathrm{C}$ in dichloromethane toremove selectively the $\mathrm{PMB}$ group at position 3; mannose derivative $\mathbf{1 0}$ was obtained in $97 \%$ yield over two steps. (Scheme 1) A double glycosylation, using 2 equivalents of thiophenyl mannopyranoside $\mathbf{1 3}$ (previously described by our group $^{21}$ as glycosyl donor, $N$-hydroxysuccinimide (NHS) and triflic acid as promoter, gave the protected trisaccharide $\mathbf{1 1}$ in $78 \%$ yield. Two deprotections steps with NaOMe in methanol to remove acetate and levulinate groups and hydrogenation using Pd on carbon as catalysts in methanol to remove benzyl groups and reduce the azide gave trisaccharide $\mathbf{2}$ in good yield. (Scheme 2). 


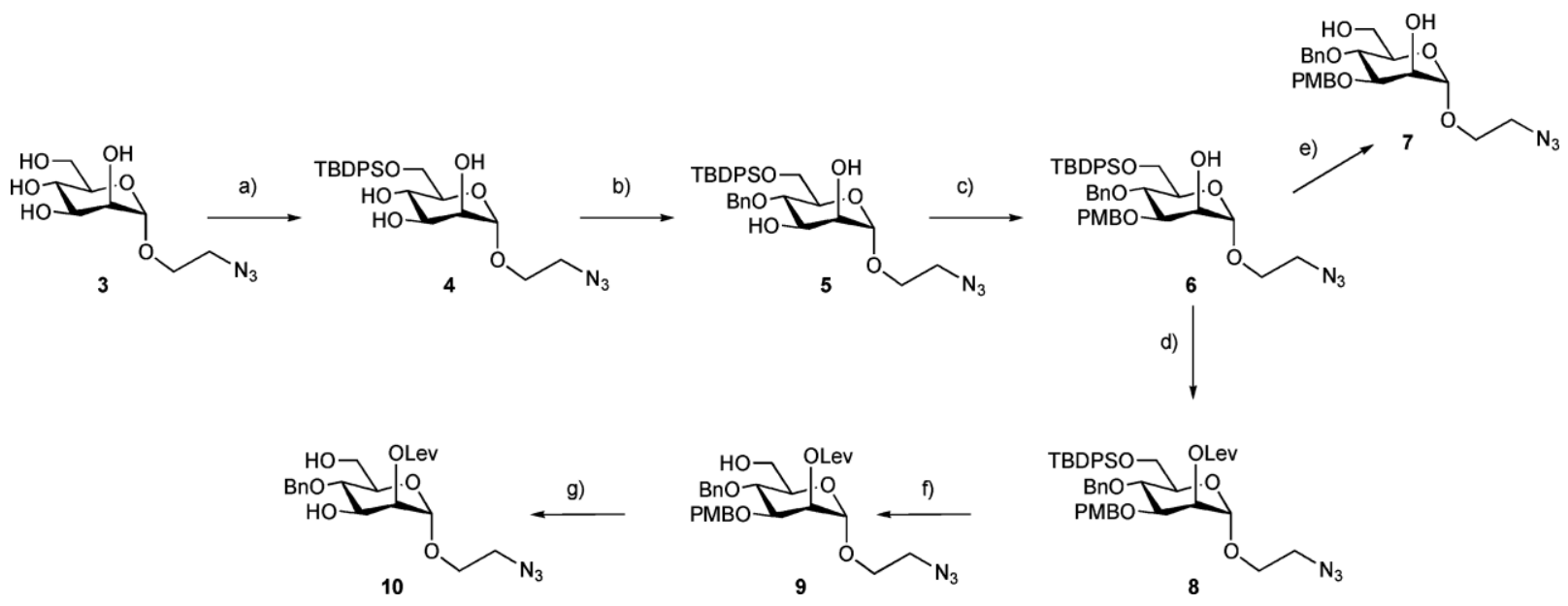

Scheme 1 Synthesis of orthogonally protected mannose derivative 8 and selective deprotections. Reagents and conditions: a) TBDPSCl, Im, DMF, rt, $79 \%$; b) 2,2 $2^{\mathbf{j}}$-dimethoxypropane, PPTS, acetone; then, $\mathrm{BnCl}$, NaH, DMF, $0{ }^{\circ} \mathrm{C}$ to rt; then, TFA DCM, rt $63 \%$ over 3 steps; c) Bu $\mathrm{SnO}$, Tol, D; then, $\mathrm{PMBCl}, \mathrm{Bu}_{4} \mathrm{NI}, \mathrm{D}, 82 \%$; d) DCC, LevOH, DCM, rt, $88 \%$; e) TBAF, THF, rt, 95\%; f) AcOH, THF, $0{ }^{\circ} \mathrm{C}$ to rt, then, TBAF, $100 \%$; g) TFA, DCM, $-20{ }^{\circ} \mathrm{C}$, $97 \%$.

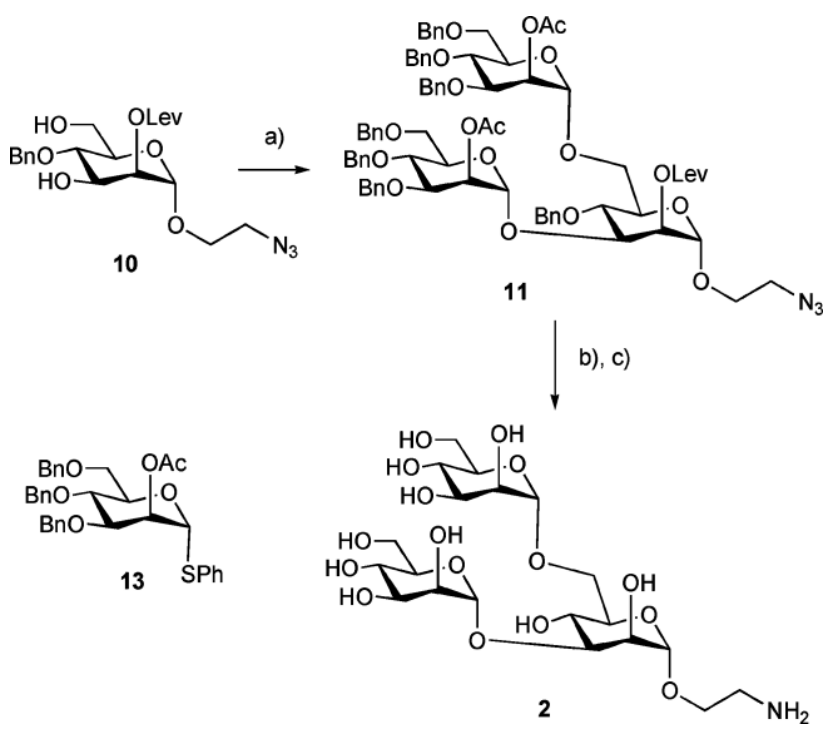

Scheme 2 Synthesis of Mana1-3[Mana1-6]Man 2. Reagents and conditions: a) $\mathbf{1 3}$ (2 equiv.), $4 \AA$ MS, NIS, TfOH, $-20{ }^{\circ} \mathrm{C}, \mathrm{DCM}, 78 \%$; b) $\mathrm{NaOMe}, \mathrm{MeOH}, \mathrm{rt}$; c) $\mathrm{H}_{2}, \mathrm{Pd}-\mathrm{C}, \mathrm{MeOH}, \mathrm{rt}, 100 \%$.

Trisaccharide 1 was prepared starting from mannose derivative 7. This trisaccharide was synthesized in three steps as shown in Scheme 3. Mannose derivative 7 was prepared from mannose 6 removing silyl group at position 6 with TBAF in THF at rt (Scheme 1). Following the same methodology used for trimannose

11, the trisaccharide $\mathbf{1 2}$ was obtained in $70 \%$ yield using 2 equivalents of mannosyl donor 13, NHS and triflic acid. Again, two deprotection steps were needed to prepare 1 using $\mathrm{NaOMe}$ in methanol and catalytic hydrogenation with $\mathrm{Pd}$ on carbon in methanol. In this way, trisaccharide $\mathbf{1}$ was obtained in good yield.

Both trisaccharides $\mathbf{1}$ and $\mathbf{2}$ show at the anomeric position an adequate linker with a terminal amine allowing their attachment to multivalent scaffolds to create carbohydrate multivalent tools. All new compounds described above were fully characterized using NMR and mass spectrometry.

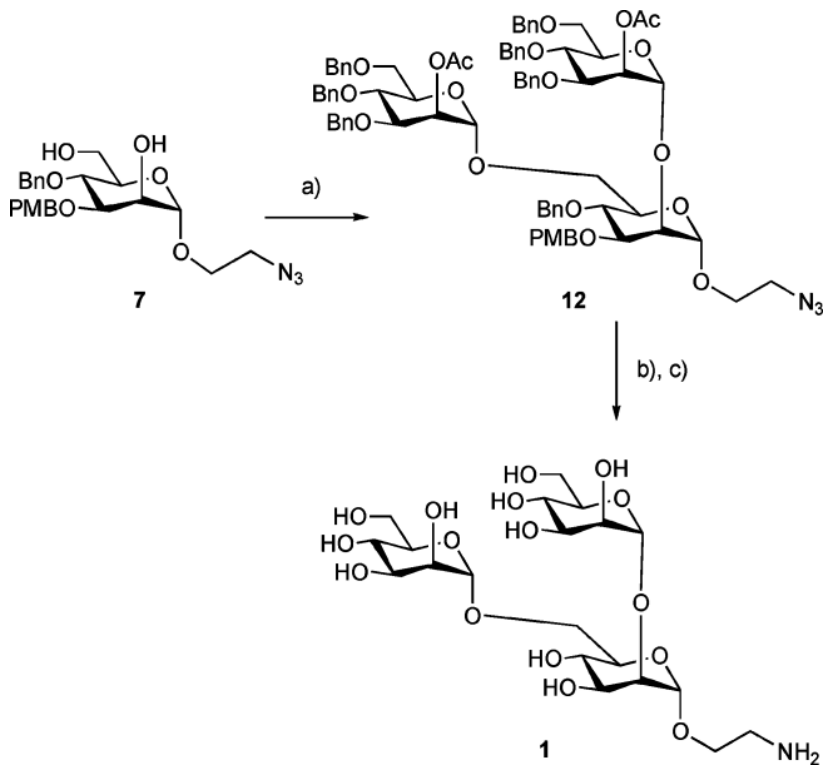

Scheme 3 Synthesis of Mana1-2[Mana1-6]Man 1. Reagents and conditions: a) $\mathbf{1 3}$ (2 equiv.), $4 \AA \mathrm{A}$, NIS, TfOH, $-20{ }^{\circ} \mathrm{C}, \mathrm{DCM}, 70 \%$; b) $\mathrm{NaOMe}, \mathrm{MeOH}, \mathrm{rt}$; c) $\mathrm{H}_{2}, \mathrm{Pd}-\mathrm{C}, \mathrm{MeOH}, \mathrm{rt}, 100 \%$.

\section{Structural analysis}

The basic structures of trisaccharides $\mathbf{1}$ and $\mathbf{2}$ are present in a wide variety of natural compounds from high mannose to GPI structures which have been extensively studied, and their 3D structures have been described both isolated or as part of larger oligosaccharides, ${ }^{21}$ and their conformational maps described in several structural databases such as Heidelberg and CERMAV. ${ }^{22}$

The interaction of trisaccharides $\mathbf{1}$ and $\mathbf{2}$ with DC-SIGN was studied by STD (saturation transfer difference) techniques determining their interaction epitopes. ${ }^{23,24}$ The bound conformations of trisaccharides $\mathbf{1}$ and $\mathbf{2}$ were also deduced from transfer-NOE experiments registered in presence of DC-SIGN ECD. ${ }^{25}$ 
Trisaccharide Mana1,2[Mana1,6]Man 1. The relative importance of each mannose unit in the binding process to DCSIGN was assessed by means of STD experiments. Several saturation times were used in order to avoid potential interferences from differences of longitudinal relaxation of the ligand protons and thus, to ensure the consistency of the results. The relative STD effects are shown on Fig. 2. The larger effects are concentrated on the 1-2 linked residue, the mannose-C, followed by the other terminal one, mannose-B, while the central one shows the lowest effects. These results could be explained based on a folded conformation where the terminal residues contact with the lectin or by the existence of several binding modes.
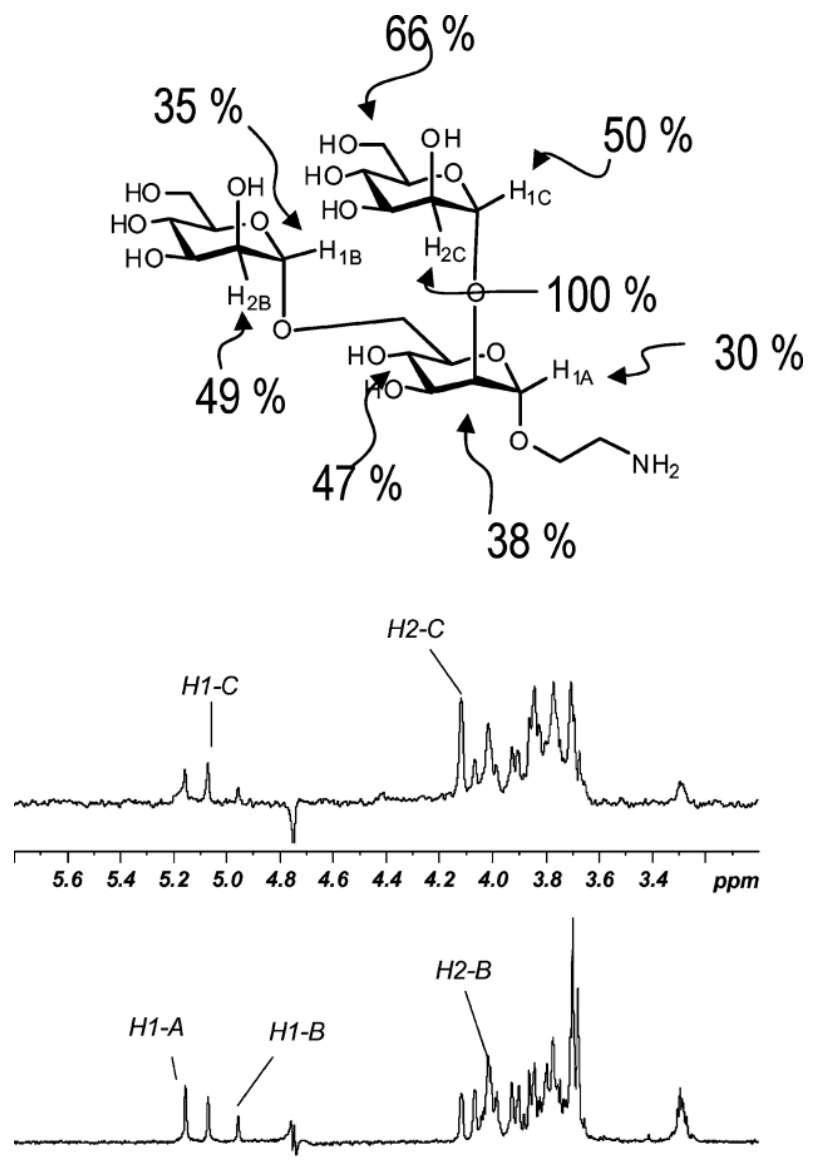

$\begin{array}{llllllllllllllll}5.6 & 5.4 & 5.2 & 5.0 & 4.8 & 4.6 & 4.4 & 4.2 & 4.0 & 3.8 & 3.6 & 3.4 & \mathrm{ppm}\end{array}$

Fig. 2 STD experiment of 1 in the presence of DC-SIGN recorded with $2.5 \mathrm{~s}$ of saturation time and absolute and relative STD values for key signals.

The conformation of $\mathbf{1}$ bound to DC-SIGN was studied by transfer NOE experiments. In the presence of $2 \%$ of the lectin, the sign of the NOE peaks was inverted (see Fig. 3) indicating ligand-receptor binding at favourable rate. The pattern of NOEs and their growing rates were not indicative that the conformation in the bound state was essentially similar to the free ligand (see supplementary information). The Man 1-2 linkage can be described mainly as an ensemble of exo-anomeric conformers with a significant degree of flexibility about the $w$ angle, which shows two relative minima. The observation of a weak NOE between $\mathrm{H} 2 \mathrm{c}$ and $\mathrm{H} 1 \mathrm{a}$ could be indicative of an increase of the population of
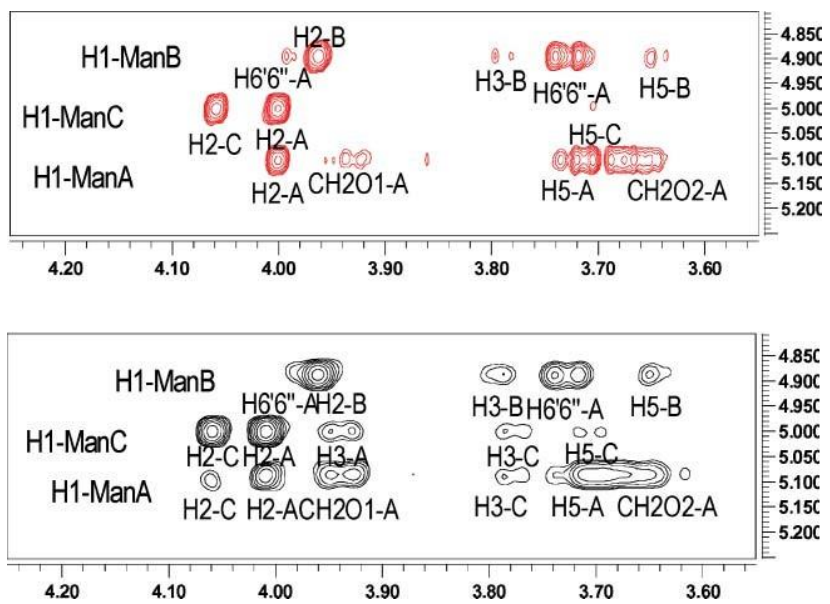

Fig. 3 Expansion of the NOESY experiments of 1, free (top) and in the presence of $1: 50$ molar of DC-SIGN (bottom), showing the NOE peaks representative of the conformation of the glycosidic linkages. Experiments registered at $500 \mathrm{MHz}$, in $150 \mathrm{mM} \mathrm{NaCl}, 20 \mathrm{mM}$ TRIS-d $64 \mathrm{mM} \mathrm{CaCl}_{2}$ at $278 \mathrm{~K}$ using a mixing time of $600 \mathrm{~ms}$ for free and $400 \mathrm{~ms}$ in presence of DC-SIGN.

non-exoanomeric conformers for the 1-2 linkage compared with the free state. The NOEs between $\mathrm{H} 1 \mathrm{~b}$ and $\mathrm{H} 6^{\mathbf{j}} \mathbf{a}$ and $\mathrm{H} 6^{\mathbf{i j}}$ a were clearly observed, in accord with the trans disposition of the $w$ torsion. Unfortunately, the data regarding the 1-6 linkage were not conclusive with respect to the determination of the $x$ rotamer.

Trisaccharide Mana1,3[Mana1,6]Man 2. The STD experiments for 2 were also conclusive with respect to the interaction between the trisaccharide and DC-SIGN, and clear peaks due to magnetization transfer were observed. Interestingly, the overall magnitude of the absolute STD effects was larger than that observed for the trisaccharide 1 . The relative STD values were higher for the 1-3 linked ManD, suggesting that this unit has a stronger interaction with the lectin (Fig. 4). In this case, the terminal residue ManB has a lower transference than the central one, suggesting small differences in the binding mode between both trisaccharides. The absolute STD values of both samples (Table 2) can be compared considering the similar nature of both compounds, the equivalence in concentration and in the ratio ligand to protein for both samples and that the dissociation constant can be estimated to be near high millimolar. In these

Table 2 Relative and absolute STD values for $\mathbf{1}$ and $\mathbf{2}$

\begin{tabular}{llclc}
\hline & STD Abs (1) & STD Rel & STD Abs (2) & STD Rel \\
\hline H1-A & 1.86 & 29.68 & 6.12 & 60.16 \\
H2-A & 2.38 & 38.08 & 5.42 & 63.32 \\
H4-A & 2.94 & 47.04 & 6.00 & 70.09 \\
H6-A & 2.16 & 34.56 & 3.07 & 35.86 \\
CH2O2-A & nd & - & 4.57 & 53.33 \\
H1-B & 2.51 & 40.16 & 3.82 & 44.63 \\
H2-B & 2.57 & 41.12 & 5.38 & 62.85 \\
H3-B & 3.09 & 49.36 & 6.11 & 71.38 \\
H1-C or D & 3.10 & 49.60 & 5.05 & 58.94 \\
H2-C or D & 6.25 & 100.00 & 8.56 & 100.00 \\
H4-C or D & 3.38 & 54.00 & 8.47 & 98.89 \\
H5-C or D & nd & - & 6.33 & 73.89 \\
H6-C or D & 4.12 & 65.84 & 7.13 & 83.29 \\
\hline
\end{tabular}



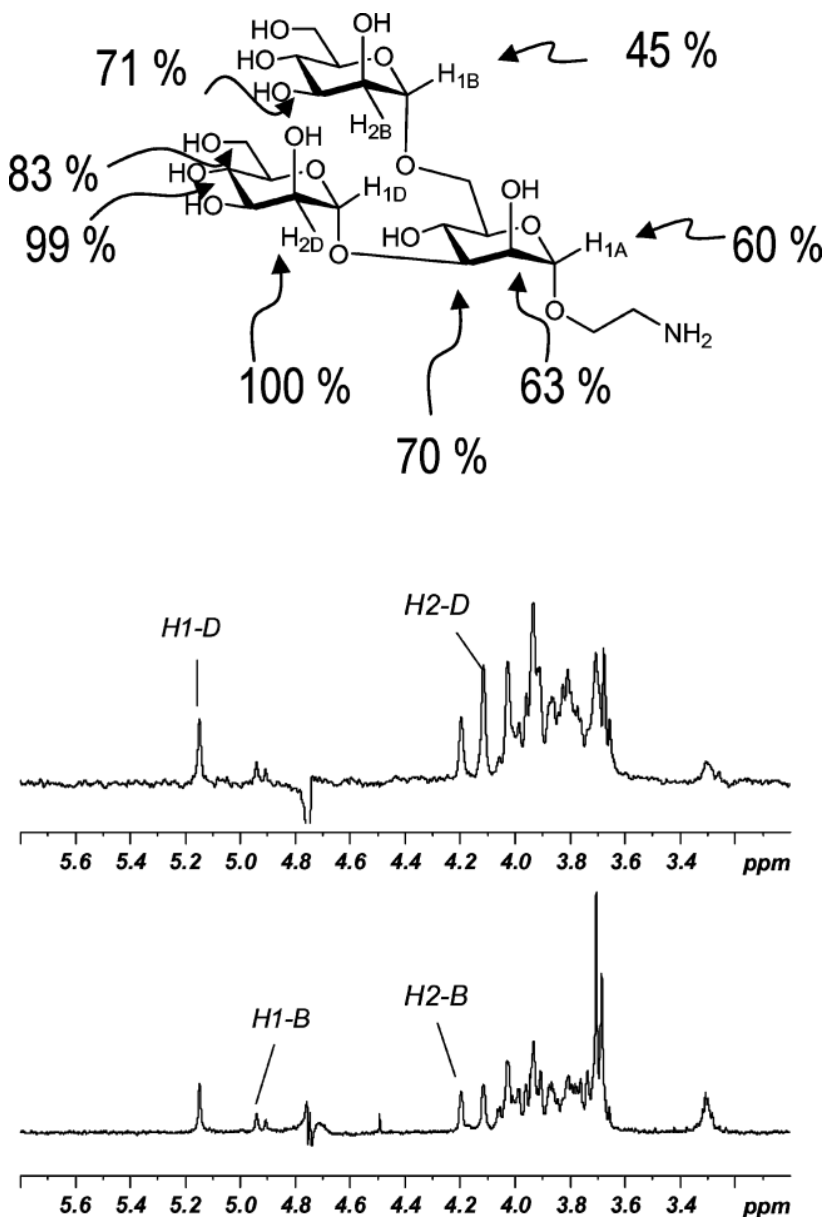

Fig. 4 STD experiment with 2 in presence of DC-SIGN recorded with $2.5 \mathrm{~s}$ of saturation time and absolute and relative STD values for significant signals.

conditions, the higher STD observed for $\mathbf{2}$ could be indicative of stronger binding than $\mathbf{1 .}^{24}$

The transfer NOESY experiments of trisaccharide 2 registered in the presence of DC-SIGN ECD showed negative NOEs indicative of transient binding of the carbohydrate to the lectin (Fig. 5). The observed differences between equivalent experiments of 2, free or with DC-SIGN, are due to the expected changes in the linewidth and correlation times. A more quantitative analysis based on the NOE growing rate does not evidence changes on key interprotonic distances (supplementary information) indicating that the relative orientation of the monosaccharidic rings is nearly the same as in the free compound, and no major conformational changes can be detected upon binding. Then the 1-3 linkage is mainly in a syn- $w$ disposition at $U$ angles compatible with the exo-anomeric effect, and the 1-6 linkage is in a trans disposition regarding the $w$ torsion but the $x$ rotamer could not be defined.

\section{Conclusions}

Herein, we have described a combined approach based on docking analysis, synthesis and NMR to study the interaction of carbohydrate ligands (mannosyl di- and trisaccharides) with the carbohydrate recognition domain of the lectin DC-SIGN and to evaluate their binding modes.
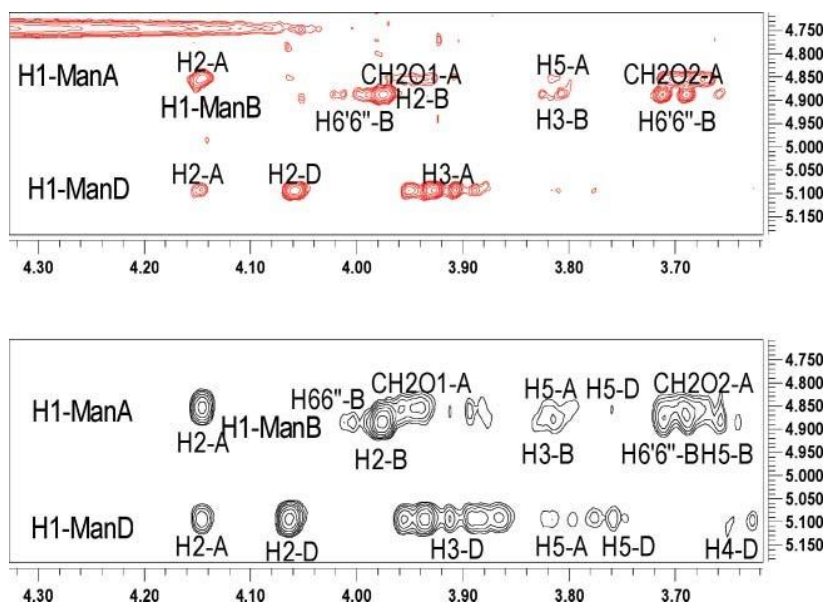

Fig. 5 Expansion of the NOESY experiments of 2, free (top) and in presence of $1: 50$ molar of DC-SIGN (bottom), showing the NOE peaks indicative of the conformation of the glycosidic linkages. Experiments registered at $500 \mathrm{MHz}$, in $150 \mathrm{mM} \mathrm{NaCl}, 20 \mathrm{mM}$ TRIS- $\mathrm{d}_{6} 4 \mathrm{mM} \mathrm{CaCl}_{2}$ at $278 \mathrm{~K}$ using a mixing time of $600 \mathrm{~ms}$ for free and $400 \mathrm{~ms}$ in presence of DC-SIGN.

The docking study reveals the existence of two potential binding sites for disaccharides indicating that only the main binding site, which contains the $\mathrm{Ca}^{2+}$ atom, yields stable complexes. This finding is supported by the lack of STD effect in the absence of $\mathrm{Ca}^{2+}$ (data not shown). Our study also has disclosed two modes of recognition differing in the orientation of the carbohydrate in the primary binding site. These modes differ in the terminal hexose that is bound to the $\mathrm{Ca}^{2+}$ atom in the main binding site. This observation agrees with the crystallographic analysis of DC-SIGN with di- and hexasaccharides, containing Mana1,2Man moieties, recently solved. ${ }^{14}$ Our results for the complex with Mana1,2Man, have shown that in the main orientation the reducing end of the disaccharide binds the $\mathrm{Ca}^{2+}$ and the structure is superimposible with the crystallographic one (Fig. 6). Moreover, an alternative docking solution points to an additional mode of binding with the $\mathrm{Ca}^{2+}$ atom through the reducing end hexose. This mode seems similar to the structure of the disaccharide in the minor $\operatorname{Man}_{6 \mathrm{~b}}$ ligand orientation in the crystallographic study.

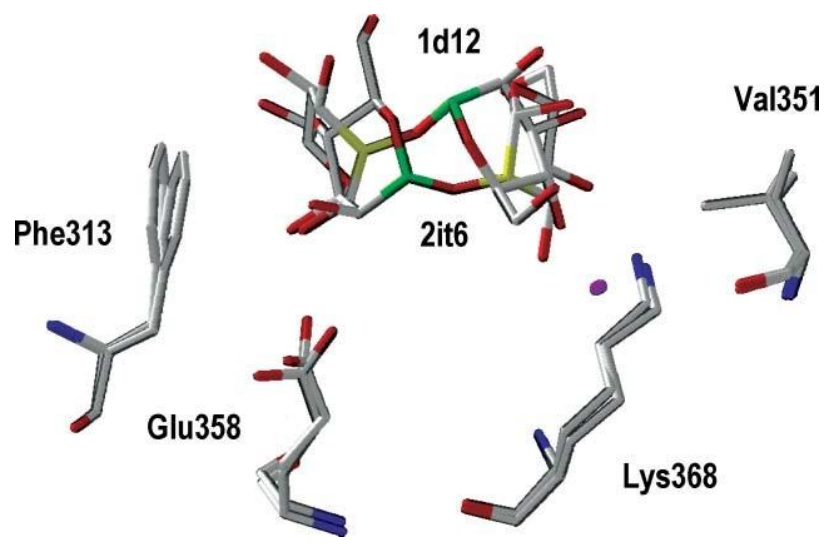

Fig. 6 Superimposition of DC-SIGN/Mana1-2Man (1d12) complex obtained from the theoretical docking calculation and from the $3 \mathrm{D}$ structure of disaccharides (pdb code 2it6). Only the binding pocket with the representative residues is represented here. 
Based on the computational analysis, two branched trisaccharides (Mana1,2[Mana1,6]Man and Mana1,3[Mana1,6]Man) were selected as the best candidates to be prepared and studied by NMR. These trisaccharides contain as part of their structure the 1-2, 1-3 and 1-6 disaccharides presented in high mannose structures. Moreover, the Mana1,3[Mana1,6]Man is a key moiety of high mannose and it is considered as one of the most important trisaccharides interacting with DC-SIGN. On the other hand, the trisaccharide Mana1,2[Mana1,6]Man, constitutes part of the arabinomannan oligosaccharide and the docking studies previewed a better interaction with DC-SIGN probably based on a carbohydrate-aromatic interaction with the side chain of Phe 313.

The conformational analysis of both trisaccharides reveals that the geometry recognized by the receptor is comparable with the conformation in the free state and therefore, there are not any large conformational changes upon binding. These structures agree in essence with those predicted by us using docking or with the crystallographic data. ${ }^{14}$ The docked models of the trisaccharides $\mathbf{1}$ and $\mathbf{2}$ showed that in both cases the non-reducing terminal mannoses show interactions with several residues of DC-SIGN while the central mannose, ManA, does not. This model is in agreement with the STD experiments and indicates that the terminal 1-2 or 1-3 linked mannoses have the closest interaction with the lectin. This is the hexose that docking structures have shown is in contact with the $\mathrm{Ca}^{2+}$ atom on the primary binding site. Additionally, this mode of binding, similar to a half moon, is somewhat similar to that found for the structure of GlcNAc $\mathrm{Man}_{3}$ and DC-SIGN (pdb code $1 \mathrm{k} 9 \mathrm{i}$, see supplementary information). On the contrary, terminal mannoses B, 1-6 linked to the central one, receive lower levels of magnetization suggesting a looser interaction with DC-SIGN. Finally, although the theoretical structures predict the lowest interactions for the central residue, experimentally this is only true for the trisaccharide $\mathbf{1}$ but not for $\mathbf{2}$. This observation, together with appreciable differences in the STD pattern also indicate potential variations in the binding modes of both compounds, probably as consequence of the existence of multiple binding modes as proposed by Seeberger and coworkers. $^{14}$

These results could be important in the future for the design of new ligands for this receptor. In particular, the observation, predicted by the docked structures and supported by the experimental relative STD values, that in both trisaccharides the nonreducing end 1-2 or 1-3 linked to the central mannose is the most involved in the interaction with the lectin, independent of the regiochemistry and relative disposition of the linkage, should be considered. Evaluation of the antiviral activity of synthesized diand trisaccharides are being carried out. Very preliminary results in an Ebola infection model indicates that trisaccharide $\mathbf{1}$ presents a similar activity to disaccharide Mana1,2Man and less activity than trisaccharide 2 (unpublished results). This preliminary data are in accordance with our analysis.

\section{Experimental section}

\section{General remarks}

All chemicals were obtained from Aldrich and used without further purification, unless otherwise noted. ${ }^{1} \mathrm{H}$ and ${ }^{13} \mathrm{C}$ NMR were recorded on Bruker Advance DPX 300, and DRX $500 \mathrm{MHz}$ spectrometers. Chemical shift are in ppm with respect to TMS (tetramethylsilane) using the manufacturer indirect referencing method. 2D experiments (COSY, TOCSY, ROESY, and HMQC) were done when necessary to assign the oligosaccharide spectra. Optical rotations were measured with a Perkin-Elmer 341 polarimeter. Mass spectra were carried out with an Esquire 6000 ESI-Ion Trap from Bruker Daltonics.

\section{Synthesis of 2-azidoethyl 6-O-tert-butyldiphenylsilyl- $a$-D-mannopyranoside (4)}

To a solution of $\mathbf{3}$ (945 mg, $3.80 \mathrm{mmol})$ and imidazole (388 mg, $5.7 \mathrm{mmol})$ in dry DMF $(10 \mathrm{~mL})$ was added dropwise at room temperature TBDPS-Cl $(1 \mathrm{~mL}, 5.7 \mathrm{mmol})$. The mixture was stirred over 4 hours and then concentrated under high vacuum. The mixture was diluted in $\mathrm{CH}_{2} \mathrm{Cl}_{2}(30 \mathrm{~mL})$, washed with water $(3 \times$ $30 \mathrm{~mL}$ ), dried over $\mathrm{MgSO}_{4}$ and concentrated. The residue was purified by flash chromatography on silica gel $\left(\mathrm{CH}_{2} \mathrm{Cl}_{2}: \mathrm{MeOH}\right.$ $9.5: 0.5)$ to give compound 4 as a pale oil $(1.46 \mathrm{~g}, 79 \%) .[a]_{\mathrm{D}}^{20}=$ $+16.04\left(c=0.75\right.$ in $\left.\mathrm{CHCl}_{3}\right) ;{ }^{1} \mathrm{H}$ NMR $\left(500 \mathrm{MHz}, \mathrm{CDCl}_{3}\right): d=$ $7.72-7.68\left(\mathrm{~m}, 4 \mathrm{H} ; \mathrm{H}_{\mathrm{Ph}}\right), 7.48-7.38\left(\mathrm{~m}, 6 \mathrm{H} ; \mathrm{H}_{\mathrm{Ph}}\right), 4.85(\mathrm{~d}, J=1.8 \mathrm{~Hz}$, $\left.1 \mathrm{H} ; \mathrm{H}_{1}\right), 3.97-3.77\left(\mathrm{~m}, 5 \mathrm{H} ; \mathrm{H}_{7}+2 \mathrm{H}_{6}+\mathrm{H}_{4}+\mathrm{H}_{7 \mathbf{j}}\right), 3.75-3.65(\mathrm{~m}$, $\left.1 \mathrm{H} ; \mathrm{H}_{7}\right), 3.60-3.53\left(\mathrm{~m}, 1 \mathrm{H} ; \mathrm{H}_{5}\right), 3.38-3.32\left(\mathrm{~m}, 2 \mathrm{H} ; 2 \mathrm{H}_{8}\right), 1.01(\mathrm{~s}$, $\left.9 \mathrm{H} ; \mathrm{H}_{\mathrm{TBDPS}}\right) ;{ }^{13} \mathrm{C} \mathrm{NMR}\left(125 \mathrm{MHz}, \mathrm{CDCl}_{3}\right): d=135.6\left(\mathrm{CH}_{\mathrm{TBDPS}}\right)$, 132.8 ( $\left.\mathrm{C}_{\mathrm{TBDPS}}\right), 132.7$ ( $\left.\mathrm{C}_{\mathrm{TBDPS}}\right), 129.9\left(\mathrm{C}_{\mathrm{TBDPS}}\right), 127.9\left(\mathrm{CH}_{\mathrm{TBDPS}}\right)$, $99.7\left(C_{1}\right), 71.5\left(C_{3}\right.$ or $\left.C_{4}\right), 70.9\left(C_{5}\right), 70.4\left(C_{3}\right.$ or $\left.C_{4}\right), 66.5\left(C_{7}\right)$, $65.2\left(\mathrm{C}_{6}\right), 50.5\left(\mathrm{C}_{8}\right), 26.8\left(\mathrm{CH}_{3 \text { TвDPS }}\right), 19.2\left(\mathrm{C}_{\mathrm{TBDPS}}\right)$; ESI-MS for $\mathrm{C}_{24} \mathrm{H}_{33} \mathrm{~N}_{3} \mathrm{O}_{6} \mathrm{Si}$; calcd: $487.2 \mathrm{M}^{+}$; found: $510.2[\mathrm{M}+\mathrm{Na}]^{+}$; elemental analysis calcd $(\%)$ for $\mathrm{C}_{24} \mathrm{H}_{33} \mathrm{~N}_{3} \mathrm{O}_{6} \mathrm{Si}: \mathrm{C}, 59,11 \% ; \mathrm{H}, 6,82 \% ; \mathrm{N}$, $8,62 \%$; found: C, $59,53 \%$; $\mathrm{H}, 7,07 \%$; N, $8,74 \%$.

\section{Synthesis of 2-azidoethyl 4-O-benzyl-6- $O$ - (tert-butyldiphenylsilyl)- $a$-D-mannopyranoside (5)}

Mannose derivative 4 ( $1.17 \mathrm{~g}, 2.4 \mathrm{mmol}), 2,2^{\mathbf{j}}$-dimethoxypropane $(2.7 \mathrm{~mL})$ and PPTS $(29 \mathrm{mg}, 0.11 \mathrm{mmol})$ were dissolved in acetone $(20 \mathrm{~mL})$ and the solution was stirred for 24 hours. $\mathrm{Et}_{3} \mathrm{~N}$ was added to the reaction mixture and the solvent was removed under vacuum. The residue and benzyl bromide $(0.45 \mathrm{~mL}, 3.8 \mathrm{mmol})$ were dissolved in dry DMF (20 mL), and $\mathrm{NaH}$ (222 mg, $3.8 \mathrm{mmol})$ was added in small portions at $0{ }^{\circ} \mathrm{C}$. The reaction mixture was stirred during 12 hours at room temperature. Then, $\mathrm{MeOH}(1 \mathrm{~mL})$ was added to the reaction to quench the excess of $\mathrm{NaH}$ and the solvent was evaporated. $\mathrm{Et}_{2} \mathrm{O}(100 \mathrm{~mL})$ was added to the reaction residue, washed with $\mathrm{H}_{2} \mathrm{O}(2 \times 100 \mathrm{~mL})$, dried over $\mathrm{MgSO}_{4}$ and concentrated. The residue was dissolved in $\mathrm{CH}_{2} \mathrm{Cl}_{2}(60 \mathrm{~mL})$ and TFA $(10 \mathrm{~mL})$ was added to the reaction at room temperature. The solution was stirred over 5 hours. A mixture of ice-water at $0{ }^{\circ} \mathrm{C}$ was added to the reaction, neutralized with $\mathrm{NaHCO}_{3}$ sat. $(100 \mathrm{~mL})$, washed with $\mathrm{NaHCO}_{3}$ sat. $(2 \times 50 \mathrm{~mL})$ and $\mathrm{NaCl}$ sat. $(100 \mathrm{~mL})$, dried with $\mathrm{MgSO}_{4}$ and the solvent was removed under vacuum. The residue was purified by flash chromatography on silica gel (toluene-AcOEt, $9: 1$ ), to give compound $\mathbf{5}$ as an oil (843 mg, 63\% over three steps). $[a]_{\mathrm{D}}^{20}=+16.02$ ( $c=0.75$ in $\left.\mathrm{CHCl}_{3}\right) ;{ }^{1} \mathrm{H}$ NMR (300 MHz, $\left.\mathrm{CDCl}_{3}\right): d=7.76-7.68(\mathrm{~m}, 4 \mathrm{H}$; $\left.\mathrm{H}_{\text {TBDPS }}\right), 7.47-7.20\left(\mathrm{~m}, 11 \mathrm{H} ; 5 \mathrm{H}_{\mathrm{Bn}}\right.$ and $\left.6 \mathrm{H}_{\mathrm{TBDPS}}\right), 4.89\left(\mathrm{~s}, 1 \mathrm{H} ; \mathrm{H}_{1}\right)$, 4.69 (syst $\left.\mathrm{AB}_{\mathrm{Bn}}, 2 \mathrm{H}\right), 4.02-3.90\left(\mathrm{~m}, 4 \mathrm{H} ; \mathrm{H}_{2}+\mathrm{H}_{3}+2 \mathrm{H}_{6}\right.$ ), 3.85 (dt, $J=10.5$ and $\left.4.9 \mathrm{~Hz}, 1 \mathrm{H} ; \mathrm{H}_{7}\right), 3.81-3.65\left(\mathrm{~m}, 2 \mathrm{H} ; \mathrm{H}_{4}\right.$ and $\left.\mathrm{H}_{5}\right), 3.59$ 
$\left(\mathrm{dt}, J=10.5\right.$ and $\left.4.9 \mathrm{~Hz}, 1 \mathrm{H} ; \mathrm{H}_{7 \mathbf{j}}\right), 3.38-3.32\left(\mathrm{~m}, 2 \mathrm{H} ; 2 \mathrm{H}_{8}\right), 1.07$ $\left(\mathrm{s}, 9 \mathrm{H} ; \mathrm{H}_{\mathrm{TBDPS}}\right) ;{ }^{13} \mathrm{C} \mathrm{NMR}\left(75 \mathrm{MHz}, \mathrm{CDCl}_{3}\right): d=138.6\left(\mathrm{C}_{\mathrm{TBDPS}}\right)$, $136.3\left(\mathrm{CH}_{\mathrm{TBDPS}}\right), 136.0\left(\mathrm{CH}_{\mathrm{TBDPS}}\right), 133.9\left(\mathrm{C}_{\mathrm{Ar}}\right), 133.6\left(\mathrm{C}_{\mathrm{Ar}}\right), 130.1$ $\left(\mathrm{CH}_{\mathrm{Ar}}\right), 129.0\left(\mathrm{CH}_{\mathrm{Ar}}\right), 128.3\left(\mathrm{CH}_{\mathrm{Ar}}\right), 128.3\left(\mathrm{CH}_{\mathrm{Ar}}\right), 128.1\left(\mathrm{CH}_{\mathrm{Ar}}\right)$, $128.1\left(\mathrm{CH}_{\mathrm{Ar}}\right), 128.1\left(\mathrm{CH}_{\mathrm{Ar}}\right), 128.0\left(\mathrm{CH}_{\mathrm{Ar}}\right), 99.9\left(\mathrm{C}_{1}\right), 77.6\left(\mathrm{C}_{5}\right.$ or $\left.\mathrm{C}_{4}\right), 77.2\left(\mathrm{CH}_{2 \mathrm{Bn}}\right), 75.2\left(\mathrm{C}_{5}\right.$ or $\left.\mathrm{C}_{4}\right), 72.9\left(\mathrm{C}_{2}\right.$ or $\left.\mathrm{C}_{3}\right), 72.0\left(\mathrm{C}_{2}\right.$ or $\left.\mathrm{C}_{3}\right), 66.7\left(\mathrm{C}_{7}\right), 63.5\left(\mathrm{C}_{6}\right), 50.9\left(\mathrm{C}_{8}\right), 27.2\left(\mathrm{CH}_{3 \mathrm{TBDPS}}\right), 19.7\left(\mathrm{C}_{\mathrm{TBDPS}}\right)$; ESI-MS for $\mathrm{C}_{31} \mathrm{H}_{39} \mathrm{~N}_{3} \mathrm{O}_{6} \mathrm{Si}$; calcd: $577.3 \mathrm{M}^{+}$; found: $600.3[\mathrm{M}+$ $\mathrm{Na}]^{+}$; elemental analysis calcd $(\%)$ for $\mathrm{C}_{31} \mathrm{H}_{39} \mathrm{~N}_{3} \mathrm{O}_{6} \mathrm{Si}$ : C, 64.14\%; $\mathrm{H}, 7.07 \%$; N, 6.94\%; found: C, 64.45\%; H, 6.80\%; N, 7.27\%.

Synthesis of 2-azidoethyl 4- $O$-benzyl-3- $O$-(4-methoxybenzyl)-6- $O$ tert-butyldiphenylsilyl-a-D-mannopyranoside (6)

A mixture of mannose derivative 5 ( $850 \mathrm{mg}, 1.48 \mathrm{mmol})$, dibutyltin oxide $(406 \mathrm{mg}, 1.63 \mathrm{mmol})$ in toluene $(40 \mathrm{~mL})$ was refluxed under Dean-Stark conditions for $3 \mathrm{~h}$. The reaction mixture was allowed to cool to room temperature and DMF $(2 \mathrm{~mL})$ was added to the mixture. 4-Methoxybenzyl chloride (227 lL, $1.63 \mathrm{mmol})$ and $\mathrm{Bu}_{4} \mathrm{NI}(602 \mathrm{mg}, 1.63 \mathrm{mmol})$ were added, and the mixture was heated at reflux for $3 \mathrm{~h}$. Then, the mixture was diluted with EtOAc $(50 \mathrm{~mL})$, washed with $\mathrm{H}_{2} \mathrm{O}(2 \times 00 \mathrm{~mL})$ and dried over MgSO .4 The solvent was removed under reduced pressure, followed by flash

chromatography on silica gel (toluene- $\mathrm{MeOH}, 94: 6$ ), afforded 6 as an oil $(849 \mathrm{mg}, 82 \%)$. $[a]^{20}=+12.00(c=1.00$ in $\mathrm{CHCl}) ;{ }^{1} \mathrm{H}$

NMR (300 MHz, CDCl ): $d=7.78-7.66(\mathrm{~m}, 4 \mathrm{H} ; 4 \mathrm{H}), 7.47-$ $7.23\left(\mathrm{~m}, 11 \mathrm{H} ; 2 \mathrm{H}_{\mathrm{PMB}}\right.$ and $\left.9 \mathrm{H}_{\mathrm{Ar}}\right), 6.87\left(\mathrm{~d}, J=8.6 \mathrm{~Hz}, 2 \mathrm{H} ; 2 \mathrm{H}_{\mathrm{PMB}}\right)$, $4.94(\mathrm{~d}, J=1.0 \mathrm{~Hz}, 1 \mathrm{H} ; \mathrm{H}), 4.84(\mathrm{~d}, J=10.9 \mathrm{~Hz}, 1 \mathrm{H} ; \mathrm{CH}), 4.63$ $\left(\mathrm{s}, 2 \mathrm{H} ; \mathrm{CH}_{2 \mathrm{PMB}}\right) 4.55\left(\mathrm{~d}, J=10.9 \mathrm{~Hz}, 1 \mathrm{H} ; \mathrm{CH}_{2 \mathrm{Bn}}\right), 4.09-4.04(\mathrm{~m}, 1 \mathrm{H}$;

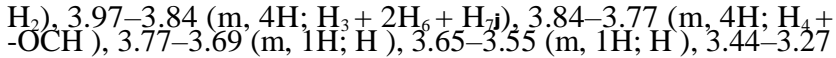
$(\mathrm{m}, 2 \mathrm{H} ; 2 \mathrm{H}), 1.05\left(\mathrm{~s}, 9 \mathrm{H} ; \mathrm{H}^{5}\right) ;{ }^{13} \mathrm{C} \mathrm{NMR}(75 \mathrm{MHz}, \mathrm{CDCl})$ : $d=159.8\left(\mathrm{C}^{8}\right), 138.7(\mathrm{C}), 136.3(\mathrm{C}), 136.0(\mathrm{C}), 134.1(\mathrm{C})$, 133.7 (C) 130.4 (C), 130.1 (C), 130.0 (C) 128.8 (C C ), 128.3 Ar $(\mathrm{C}), 128.1\left(\mathrm{C}_{\mathrm{Ar}}^{\mathrm{Ar}}\right), 128.0\left(\mathrm{C}_{\mathrm{Ar}}\right), 114.4\left(\mathrm{C}_{\mathrm{Ar}}\right), 99.6\left(\mathrm{C}_{1}^{\mathrm{Ar}}\right), 80.2\left(\mathrm{Ar}_{3}^{\mathrm{Ar}}\right), 74.4$ $\left(\mathrm{CH}_{2 \mathrm{Bn}}^{\mathrm{Ar}}\right), 73.2\left(\mathrm{C}_{5}^{\mathrm{Ar}}\right), 72.2\left(\mathrm{CH}_{2 \mathrm{PMB}}^{\mathrm{Ar}}\right), 68.7\left(\mathrm{C}_{2}\right), 66.7\left(\mathrm{C}_{7}\right), 63.6\left(\mathrm{C}_{6}\right)$,

$55.7\left(\mathrm{CH}_{3} \mathrm{O}-\right), 50.9\left(\mathrm{C}\right.$ \&, 27.2 ( $\left.\mathrm{CH}_{3 \text { TRDPS }}\right), 19.7$ (C for $\mathrm{C} \mathrm{H} \mathrm{N} \mathrm{O} \mathrm{Si;} \mathrm{calcd:} 697.3 \mathrm{M}^{+}$; found: $720.3\left[\mathrm{M}^{\text {TBDPS }}+\mathrm{Na}\right]^{+}$and $736.3^{30}\left[\mathrm{M}^{37}+\mathrm{K}\right]^{+}$; elemental analysis calcd $(\%)$ for $\mathrm{C} \mathrm{H} \mathrm{N} \mathrm{O} \mathrm{Si:}$ C, 66.96\%; H, 6.80\%; N, 5.74\%; found: C, 67.12\%; H, 6.79\%; N, $6.02 \%$.

Synthesis of 2-azidoethyl 4-O-benzyl-3-O-(4-methoxybenzyl)$a$-D-mannopyranoside (7)

Mannose derivative 6 (700 mg, $1.00 \mathrm{mmol})$ and TBAF (533 mg, $2.00 \mathrm{mmol})$ were dissolved in THF $(7 \mathrm{~mL})$. The solution was stirred under argon during 5 hours at room temperature. The solvent was removed under vacuum and the residue was purified by flash chromatography on silica gel (hexane-AcOEt, $1: 2$ ), to give compound 7 as an oil (436 mg, 95\%). $[a]^{20}=+34.5(c=0.75$ in $\left.\mathrm{CHCl}_{3}\right) ;{ }^{1} \mathrm{H}$ NMR $\left(500 \mathrm{MHz}, \mathrm{CDCl}_{3}\right): d=7.33-7.24(\mathrm{~m}, 6 \mathrm{H}$; $\left.\mathrm{H}_{\mathrm{Ar}}\right), 6.84\left(\mathrm{~d}, 2 \mathrm{H} ; 2 \mathrm{H}_{\mathrm{PMB}}\right), 4.90\left(\mathrm{~d}, J=1.5 \mathrm{~Hz}, 1 \mathrm{H} ; \mathrm{H}_{1}\right), 4.86(\mathrm{~d}$, $\left.J=11.0 \mathrm{~Hz}, 1 \mathrm{H} ; \mathrm{CH}_{2 \mathrm{PMB}}\right), 4.63\left(\mathrm{~d}, J=11.0 \mathrm{~Hz}, 1 \mathrm{H} ; \mathrm{CH}_{2 \mathrm{PMB}}\right)$, $4.60\left(\mathrm{~s}, 2 \mathrm{H} ; \mathrm{CH}_{2 \mathrm{Bn}}\right), 4.01\left(\mathrm{dd}, J=1.5\right.$ and $\left.3.1 \mathrm{~Hz}, 1 \mathrm{H} ; \mathrm{H}_{2}\right), 3.88$ (dd, $J=3.1$ and $\left.9.0 \mathrm{~Hz}, 1 \mathrm{H} ; \mathrm{H}_{3}\right) 3.86-3.79\left(\mathrm{~m}, 3 \mathrm{H} ; \mathrm{H}_{4}\right.$ and $2 \mathrm{H}_{6}$ ), $3.78\left(\mathrm{~s}, 3 \mathrm{H} ;-\mathrm{OCH}_{3}\right), 3.75\left(\mathrm{dd}, J=3.9\right.$ and $\left.12.3 \mathrm{~Hz}, 1 \mathrm{H} ; \mathrm{H}_{7 \mathbf{j}}\right)$, $3.58\left(\mathrm{dt}, J=3.9\right.$ and $\left.9.9 \mathrm{~Hz}, 1 \mathrm{H} ; \mathrm{H}_{7}\right), 3.40-3.29\left(\mathrm{~m}, 2 \mathrm{H} ; 2 \mathrm{H}_{8}\right) ;{ }^{13} \mathrm{C}$ $\operatorname{NMR}\left(\mathrm{CDCl}_{3}, 125 \mathrm{MHz}\right): d=159.5\left(\mathrm{C}_{\mathrm{Ar}}\right), 138.2\left(\mathrm{C}_{\mathrm{Ar}}\right), 129.9\left(\mathrm{C}_{\mathrm{Ar}}\right)$,
$129.7\left(\mathrm{C}_{\mathrm{Ar}}\right), 128.5\left(\mathrm{C}_{\mathrm{Ar}}\right), 128.0\left(\mathrm{C}_{\mathrm{Ar}}\right), 127.8\left(\mathrm{C}_{\mathrm{Ar}}\right), 114.0\left(\mathrm{C}_{\mathrm{Ar}}\right), 99.4$ $\left(\mathrm{C}_{1}\right), 79.5\left(\mathrm{C}_{3}\right), 75.2\left(\mathrm{CH}_{2 \mathrm{Bn}}\right), 73.8\left(\mathrm{C}_{4}\right.$ or $\left.\mathrm{C}_{5}\right), 71.9\left(\mathrm{C}_{4}\right.$ or $\left.\mathrm{C}_{5}\right), 71.8$ $\left(\mathrm{CH}_{2 \mathrm{PMB}}\right), 68.3\left(\mathrm{C}_{2}\right), 66.7\left(\mathrm{C}_{7}\right), 62.1\left(\mathrm{C}_{6}\right), 55.3\left(-\mathrm{OCH}_{3}\right), 50.5\left(\mathrm{C}_{8}\right)$; ESI-MS for $\mathrm{C}_{23} \mathrm{H}_{29} \mathrm{~N}_{3} \mathrm{O}_{7}$; calcd: $459.2 \mathrm{M}^{+}$; found: $482.3[\mathrm{M}+\mathrm{Na}]^{+}$ and $498.2[\mathrm{M}+\mathrm{K}]^{+}$; elemental analysis calcd $(\%)$ for $\mathrm{C}_{23} \mathrm{H}_{29} \mathrm{~N}_{3} \mathrm{O}_{7}$ : C, 60.12\%; H, 6.36\%; N, 9.16\%; found: C, 60.15\%; H, 6.69\%; N, $9.16 \%$.

Synthesis of 2-azidoethyl 4-O-benzyl-6-O-tert-butyldiphenylsilyl2-O-levulinoyl-3-O-(4-methoxybenzyl)- $a$-D-mannopyranoside (8)

Mannose derivative 6 (100 mg, $0.144 \mathrm{mmol}$ ) and DCC (149 mg, $0.720 \mathrm{mmol})$ were dissolved in $\mathrm{CH}_{2} \mathrm{Cl}_{2}(2 \mathrm{~mL})$ under argon. After addition of levulinic acid (146 1L, $1.44 \mathrm{mmol})$ a precipitate was observed corresponding to the urea formation. Acatalytic amount of DMAP $(8 \mathrm{mg})$ was added and the reaction was stirred at $\mathrm{rt}$ for $24 \mathrm{~h}$. The reactionmixture was diluted with $\mathrm{CH}_{2} \mathrm{Cl}_{2}(6 \mathrm{~mL})$, filtered over a pad of Celite and concentrated under vacuum. The residue was purified by flash chromatography on silica gel $\left(\mathrm{CH}_{2} \mathrm{Cl}_{2}\right.$ and $0.5 \%$ acetone) to afford $\mathbf{8}$ as an oil $(100 \mathrm{mg}, 88 \%) .[a]^{20}=+2.10$ $\left(c=0.75\right.$ in $\left.\mathrm{CHCl}_{3}\right) ;{ }^{1} \mathrm{H} \mathrm{NMR}\left(300 \mathrm{MHz}, \mathrm{CDCl}_{3}\right): d=7.76-7.65$

(m, 4H; H ph $_{2} 7.46-7.30(\mathrm{~m}, 6 \mathrm{H} ; \mathrm{H}), \underset{\mathrm{Ar}}{7.30-7.22}(\mathrm{~m}, 5 \mathrm{H} ; \mathrm{H})$, Ar $7.21-7.13\left(\mathrm{~m}, 2 \mathrm{H} ; \mathrm{H}_{\mathrm{Ar}}\right), 6.83\left(\mathrm{~d}, J=8.7 \mathrm{~Hz}, 2 \mathrm{H} ; \mathrm{H}_{\mathrm{PMB}}\right), 5.39(\mathrm{dd}$, $J=1.9$ and $\left.2.8 \mathrm{~Hz}, 1 \mathrm{H} ; \mathrm{H}_{2}\right), 4.89\left(\mathrm{~d}, J=10.6 \mathrm{~Hz}, 1 \mathrm{H} ; \mathrm{CH}_{2 \mathrm{Bn}}\right)$, $4.87\left(\mathrm{~s}, 1 \mathrm{H} ; \mathrm{H}_{1}\right), 4.62\left(\mathrm{~d}, J=10.9 \mathrm{~Hz}, 1 \mathrm{H} ; \mathrm{CH}_{2 \mathrm{PMB}}\right), 4.57(\mathrm{~d}, J=$ $10.7 \mathrm{~Hz}, 1 \mathrm{H} ; \mathrm{CH}_{2 \mathrm{Bn}}$ ), 4.45 (d, $J=10.9 \mathrm{~Hz}, 1 \mathrm{H} ; \mathrm{CH}_{2 \mathrm{PMB}}$ ), $4.03-$ $3.87\left(\mathrm{~m}, 4 \mathrm{H} ; \mathrm{H}_{3}+\mathrm{H}_{5}+2 \mathrm{H}_{6}\right), 3.87-3.77\left(\mathrm{~m}, 4 \mathrm{H} ;-\mathrm{OCH}_{3}\right.$ and $\left.\mathrm{H}_{7 \mathrm{j}}\right)$, $3.74-3.66(\mathrm{~m}, 1 \mathrm{H} ; \mathrm{H}), 3.58\left(\mathrm{dt}, J={ }_{10.6}\right.$ and $\left.5.1 \mathrm{~Hz}, 1 \mathrm{H} ; \mathrm{H}\right), 3.34$ $\left(\mathrm{t}, J=5.1 \mathrm{~Hz}, 2 \mathrm{H} ; 22^{4} \mathrm{H}\right), 2.83-2.61\left(\mathrm{~m}, 4 \mathrm{H} ; \mathrm{CH}_{2}^{\mathrm{CH}}\right), 2.51^{7}(\mathrm{~s}$, $3 \mathrm{H} ; \mathrm{CH}_{3 \text { lev }}$ ), 1.56 (s, 9H; $\left.\mathrm{CH}_{\mathrm{TBDPS}}\right) ;{ }^{13} \mathrm{C} \mathrm{NMR}\left(75 \mathrm{MHz}, \mathrm{CDCl}_{3}\right)$ : $d=206.8\left(\mathrm{CO}_{\text {lev }}\right), 172.6\left(\mathrm{COO}_{\text {lev }}\right), 159.7\left(\mathrm{C}_{\mathrm{Ar}}\right), 136.3\left(\mathrm{C}_{\mathrm{Ar}}\right), 136.0$ $\left(\mathrm{C}_{\mathrm{Ar}}\right), 134.1\left(\mathrm{C}_{\mathrm{Ar}}\right), 133.6\left(\mathrm{C}_{\mathrm{Ar}}\right), 130.5\left(\mathrm{C}_{\mathrm{Ar}}\right), 130.3\left(\mathrm{C}_{\mathrm{Ar}}\right), 128.8\left(\mathrm{C}_{\mathrm{Ar}}\right)$, $128.3\left(\mathrm{C}_{\mathrm{Ar}}\right), 128.1\left(\mathrm{C}_{\mathrm{Ar}}\right), 128.0\left(\mathrm{C}_{\mathrm{Ar}}\right), 114.2\left(\mathrm{C}_{\mathrm{Ar}}\right), 98.2\left(\mathrm{C}_{6}\right), 78.1$ $\left(\mathrm{C}_{3}\right), 75.7\left(\mathrm{CH}_{2 \mathrm{Bn}}\right), 74.3\left(\mathrm{C}_{5}\right), 73.3(\mathrm{C}), 71.8\left(\mathrm{CH}_{2 \mathrm{PMB}}\right), 69.3\left(\dot{\mathrm{C}}_{2}\right)$, $66.9\left(\mathrm{C}_{7}\right), 63.3\left(\mathrm{C}_{6}\right), 55.7\left(-\mathrm{OCH}_{3}\right), 50.8\left(\mathrm{C}_{8}\right), 38.4\left(-\mathrm{CH}_{2 l e v}\right), 30.3$ $(\mathrm{CH}), 28.5(-\mathrm{CH}), 27.2(\mathrm{CH}), 19.8(\mathrm{C})$; ESI-MS for

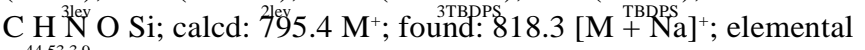
analysis calcd (\%) for C $\underset{445339}{\mathrm{~N}} \mathrm{O}$ Si: C, 66.39\%; H, 6.71\%; N, $5.28 \%$; found: C, $66.27 \%$;, $6.87 \%$; N $5.08 \%$.

\section{Synthesis of 2-azidoethyl 4-O-benzyl-2-O-levulinoyl-3-O-(4- methoxybenzyl)- $a$-D-mannopyranoside (9)}

Acetic acid (150 lL) was added slowly to a solution of $8(215 \mathrm{mg}$, $0.270 \mathrm{mmol})$ in dry THF $(2 \mathrm{~mL})$, under nitrogen at $0{ }^{\circ} \mathrm{C}$. The solution was warmed up to room temperature and TBAF $1 \mathrm{M}$ in THF (330 lL, $0.33 \mathrm{mmol}$ ) was added to the solution. The solution was stirred overnight and then the solvent was removed under vacuum. The residue was purified by flash chromatography on silica gel (hexane-AcOEt, $1: 2$ ) to give compound 9 as an oil (150 mg, quant.). $\left[a b^{20}=+13.02\left(c=0.4\right.\right.$ in $\left.\mathrm{CHCl}_{3}\right) ;{ }^{1} \mathrm{H}$ NMR $\left(300 \mathrm{MHz}, \mathrm{CDCl}_{3}\right): d=7.38-7.21\left(\mathrm{~m}, 7 \mathrm{H} ; 5 \mathrm{H}_{\mathrm{Bn}}\right.$ and $\left.2 \mathrm{H}_{\mathrm{PMB}}\right), 6.84$ $\left(\mathrm{d}, J=8.7 \mathrm{~Hz}, 2 \mathrm{H} ; 2 \mathrm{H}_{\mathrm{PMB}}\right), 5.34(\mathrm{dd}, J=3.1$ and $1.8 \mathrm{~Hz}, 1 \mathrm{H}$; $\left.\mathrm{H}_{2}\right), 4.90\left(\mathrm{~d}, J=10.9 \mathrm{~Hz}, 1 \mathrm{H} ; \mathrm{CH}_{2 \mathrm{Bn}}\right), 4.86(\mathrm{~d}, J=1.6 \mathrm{~Hz}, 1 \mathrm{H}$; $\left.\mathrm{H}_{1}\right), 4.61\left(\mathrm{~d}, J=10.9 \mathrm{~Hz}, 1 \mathrm{H} ; \mathrm{CH}_{2 \mathrm{Bn}}\right), 4.61(\mathrm{~d}, J=10.9 \mathrm{~Hz}$, $\left.1 \mathrm{H} ; \mathrm{CH}_{2 \mathrm{Bn}}\right), 4.45\left(\mathrm{~d}, J=10.9 \mathrm{~Hz}, 1 \mathrm{H} ; \mathrm{CH}_{2 \mathrm{Bn}}\right), 4.00(\mathrm{dd}, J=3.3$ and $\left.9.1 \mathrm{~Hz}, 1 \mathrm{H} ; \mathrm{H}_{3}\right), 3.89-3.66\left(\mathrm{~m}, 5 \mathrm{H} ; \mathrm{H}_{4}+\mathrm{H}_{5}+2 \mathrm{H}_{6}+\mathrm{H}_{7}\right)$, $3.59\left(\mathrm{dt}, J=10.3\right.$ and $\left.4.9 \mathrm{~Hz}, 1 \mathrm{H} ; \mathrm{H}_{7 \mathbf{j}}\right), 3.37(\mathrm{t}, J=4.9 \mathrm{~Hz}, 2 \mathrm{H}$; 
$\left.2 \mathrm{H}_{8}\right), 2.87-2.57$ (m, 4H; $\left.\mathrm{CH}_{2} \mathrm{CH}_{2 \mathrm{lev}}\right), 2.18$ (s, 3H; $\left.\mathrm{CH}_{3 \mathrm{lev}}\right) ;{ }^{13} \mathrm{C} \mathrm{NMR}$ $\left(75 \mathrm{MHz}, \mathrm{CDCl}_{3}\right): d=206.9\left(\mathrm{CO}_{\mathrm{lev}}\right), 172.5\left(\mathrm{COO}_{\mathrm{lev}}\right), 159.7\left(\mathrm{C}_{\mathrm{PMB}}\right)$, 138.6 $\left(\mathrm{C}_{\mathrm{Ar}}\right), 130.4\left(\mathrm{C}_{\mathrm{Ar}}\right), 130.2\left(\mathrm{C}_{\mathrm{Ar}}\right), 128.9\left(\mathrm{C}_{\mathrm{Ar}}\right), 128.5\left(\mathrm{C}_{\mathrm{Ar}}\right), 128.3$ $\left(\mathrm{C}_{\mathrm{Ar}}\right), 114.2\left(\mathrm{C}_{\mathrm{Ar}}\right), 98.2\left(\mathrm{C}_{1}\right), 77.8\left(\mathrm{C}_{3}\right), 75.6\left(\mathrm{CH}_{2 \mathrm{Bn}}\right), 74.2\left(\mathrm{C}_{4}\right.$ or $\left.\mathrm{C}_{5}\right), 72.5\left(\mathrm{C}_{4}\right.$ or $\left.\mathrm{C}_{5}\right), 71.8\left(\mathrm{CH}_{2 \mathrm{Bn}}\right), 69.2\left(\mathrm{C}_{2}\right), 67.2\left(\mathrm{C}_{7}\right), 62.5\left(\mathrm{C}_{6}\right)$, $55.7\left(-\mathrm{OCH}_{3}\right), 50.8\left(\mathrm{C}_{8}\right), 38.5\left(\mathrm{CH}_{2 \mathrm{lev}}\right), 30.2\left(\mathrm{CH}_{3 \mathrm{lev}}\right), 28.5\left(\mathrm{CH}_{2 \mathrm{lev}}\right)$; ESI-MS for $\mathrm{C}_{28} \mathrm{H}_{35} \mathrm{~N}_{3} \mathrm{O}_{9}$; calcd: $557.2 \mathrm{M}^{+}$; found: $596.1[\mathrm{M}+\mathrm{Na}]^{+}$ and $580.1[\mathrm{M}+\mathrm{K}]^{+}$; elemental analysis calcd $(\%)$ for $\mathrm{C}_{28} \mathrm{H}_{35} \mathrm{~N}_{3} \mathrm{O}_{9}$ : C, 59.66\%; H, 6.12\%; N, 7.73\%; found: C, 59.84\%; H, 6.00\%; N, $7.74 \%$.

\section{Synthesis of 2-azidoethyl 4-O-benzyl-2- $O$-levulinoyl- $a$-D-mannopyranoside (10)}

Mannose derivative 9 (74 $\mathrm{mg}, 0.126 \mathrm{mmol})$ was dissolved in $\mathrm{CH}_{2} \mathrm{Cl}_{2}(5 \mathrm{~mL})$, the solution was cooled at-20 ${ }^{\circ} \mathrm{C}$ and TFA $(1.5 \mathrm{~mL})$ was added to the solution. The reaction mixture was stirred during $20 \mathrm{~min}$. Then, ethanol $(0.5 \mathrm{~mL})$ and $\mathrm{CH}_{2} \mathrm{Cl}_{2}$ $(4 \mathrm{~mL})$ were added to the reaction. The solution was washed with $\mathrm{NaHCO}_{3}$ sat. $(2 \times 10 \mathrm{~mL}), \mathrm{NaCl}$ sat. $(10 \mathrm{~mL})$, and dried with $\mathrm{MgSO}_{4}$. The solvent was removed under vacuum and the residue was purified by flash chromatography on silica gel (hexaneAcOEt, 2: 1) to give compound 10 as and oil (53 mg, 97\%). $[a]_{\mathrm{D}}^{20}=$ +32.91 $\left(c=0.70\right.$ in $\left.\mathrm{CHCl}_{3}\right) ;{ }^{1} \mathrm{H}$ NMR $\left(300 \mathrm{MHz}, \mathrm{CDCl}_{3}\right): d=$ 7.40-7.31 (m, 4H; 4H $\left.\mathrm{H}_{\mathrm{Bn}}\right), 7.31-7.25\left(\mathrm{~m}, 1 \mathrm{H} ; \mathrm{H}_{\mathrm{Bn}}\right), 5.13(\mathrm{dd}, J=2.0$ and $\left.3.3 \mathrm{~Hz}, 1 \mathrm{H} ; \mathrm{H}_{2}\right), 4.87\left(\mathrm{~d}, J=10.9 \mathrm{~Hz}, 1 \mathrm{H} ; \mathrm{CH}_{2 \mathrm{Bn}}\right), 4.82(\mathrm{~d}, J=$ $\left.1.2 \mathrm{~Hz}, 1 \mathrm{H} ; \mathrm{H}_{1}\right), 4.71\left(\mathrm{~d}, J=10.9 \mathrm{~Hz}, 1 \mathrm{H} ; \mathrm{CH}_{2 \mathrm{Bn}}\right), 4.19-4.13(\mathrm{~m}$, $\left.1 \mathrm{H} ; \mathrm{H}_{3}\right), 3.89-3.76\left(\mathrm{~m}, 3 \mathrm{H} ; 2 \mathrm{H}_{6}\right.$ and $\left.\mathrm{H}_{7 \mathbf{j}}\right), 3.75-3.64\left(\mathrm{~m}, 2 \mathrm{H} ; \mathrm{H}_{4}\right.$ and $\left.\mathrm{H}_{5}\right), 3.61-3.55\left(\mathrm{~m}, 1 \mathrm{H} ; \mathrm{H}_{7}\right), 3.42-3.32\left(\mathrm{~m}, 2 \mathrm{H} ; 2 \mathrm{H}_{8}\right), 2.84-2.75$ (m, 2H; $\mathrm{CH}_{2 \mathrm{lev}}$ ), 2.67-2.59 (m, 2H; $\left.\mathrm{CH}_{2 \mathrm{lev}}\right), 2.19\left(\mathrm{~s}, 3 \mathrm{H} ; \mathrm{CH}_{3 \mathrm{lev}}\right) ;{ }^{13} \mathrm{C}$ NMR $\left(75 \mathrm{MHz}, \mathrm{CDCl}_{3}\right): d=207.1\left(\mathrm{CO}_{\text {lev }}\right), 170.1\left(\mathrm{COO}_{\text {lev }}\right), 133.7$ $\left(\mathrm{C}_{\mathrm{Ar}}\right), 133.2\left(\mathrm{C}_{\mathrm{Ar}}\right), 130.6\left(\mathrm{C}_{\mathrm{Ar}}\right), 129.6\left(\mathrm{C}_{\mathrm{Ar}}\right), 127.5\left(\mathrm{C}_{\mathrm{Ar}}\right), 127.4\left(\mathrm{C}_{\mathrm{Ar}}\right)$, $97.5\left(\mathrm{C}_{1}\right), 75.7\left(\mathrm{C}_{4}\right.$ or $\left.\mathrm{C}_{5}\right), 72.7\left(\mathrm{C}_{2}\right), 72.0\left(\mathrm{C}_{4}\right.$ or $\left.\mathrm{C}_{5}\right), 70.1(\mathrm{C}-3), 66.6$ $\left(\mathrm{C}_{7}\right), 61.7\left(\mathrm{C}_{6}\right), 50.4\left(\mathrm{C}_{8}\right), 38.4\left(\mathrm{CH}_{2 \mathrm{lev}}\right), 29.7\left(\mathrm{CH}_{3 \mathrm{lev}}\right), 28.4\left(\mathrm{CH}_{2 \mathrm{lev}}\right)$; ESI-MS for $\mathrm{C}_{20} \mathrm{H}_{27} \mathrm{~N}_{3} \mathrm{O}_{8}$; calcd: $437.2 \mathrm{M}^{+}$; found: $460.2[\mathrm{M}+\mathrm{Na}]^{+}$; elemental analysis calcd (\%) for $\mathrm{C}_{20} \mathrm{H}_{27} \mathrm{~N}_{3} \mathrm{O}_{8}$ : C, 53.90\%; H, 5.95\%; $\mathrm{N}, 9.92 \%$; found: C, $53.99 \%$;, $5.75 \% ; \mathrm{N}, 10.14 \%$.

\section{Synthesis of 2-azidoethyl $O$-(2- $O$-acetyl-3,4,6-tri- $O$-benzyl- $a$-D- mannopyranosyl-( $1 \rightarrow 3$ )- $O$-[2- $O$-acetyl-3,4,6-tri- $O$-benzyl- $a$-D-mannopyranosyl-(1 $\rightarrow 6)]-4-O$-benzyl-2- $O$-levulinoyl- $a$-D-mannopyranoside (11)}

Mannose derivative 10 (40 $\mathrm{mg}, 0.092 \mathrm{mmol}$ ), and the glycosyl donor 13 (146 mg, $0.249 \mathrm{mmol}$ ) were dissolved in dry $\mathrm{CH}_{2} \mathrm{Cl}_{2}$ ( $2 \mathrm{~mL})$ in the presence of $4 \AA$ molecular sieves. The mixture was stirred during 2 hour at room temperature under argon atmosphere. Then, the system was cooled at $-20^{\circ} \mathrm{C}$, NIS $(56 \mathrm{mg}$, $0.249 \mathrm{mmol})$ and TfOH $(2.5 \mathrm{lL}, 0.026 \mathrm{mmol})$ were added and the mixture was stirred during $20 \mathrm{~min}$. The reaction was monitored by TLC (toluene- $\mathrm{MeOH}, 9: 1$ ) and when it was completed, $\mathrm{NaHCO}_{3}$ sat. $(50 \mathrm{lL})$ was added to quench the $\mathrm{TfOH}$. The reaction mixture was diluted with $\mathrm{CH}_{2} \mathrm{Cl}_{2}(6 \mathrm{~mL})$, filtered over a pad of Celite, washed with $\mathrm{Na}_{2} \mathrm{~S}_{2} \mathrm{O}_{3}$ sat., dried over $\mathrm{MgSO}_{4}$ and the solvent was removed under vacuum. The residue was purified by flash chromatography on silica gel (hexane : AcOEt, $7: 1)$ to give compound 11 as an oil $(91 \mathrm{mg}, 72 \%)$. $[a]^{20}=+45.76(c=1.00$ in $\left.\mathrm{CHCl}_{3}\right) ;{ }^{1} \mathrm{H} \mathrm{NMR}\left(500 \mathrm{MHz}, \mathrm{CDCl}_{3}\right): d=7.47-7.16(\mathrm{~m}, 32 \mathrm{H}$; $\left.\mathrm{H}_{\mathrm{ArBn}}\right), 5.49\left(\mathrm{dd}, J=3.5 \mathrm{~Hz}\right.$ and $\left.1.5 \mathrm{~Hz}, 1 \mathrm{H} ; \mathrm{H}_{2}\right), 4.47(\mathrm{dd}, J=$
$3.5 \mathrm{~Hz}$ and $\left.1.5 \mathrm{~Hz}, 1 \mathrm{H} ; \mathrm{H}_{2}\right), 5.22-5.18\left(\mathrm{~m}, 2 \mathrm{H} ; \mathrm{H}_{2}\right.$ and $\left.\mathrm{H}_{1}\right), 5.03$ $\left(\mathrm{d}, J=1.5 \mathrm{~Hz}, 1 \mathrm{H} ; \mathrm{H}_{1}\right), 4.89\left(\mathrm{~d}, J=11.0 \mathrm{~Hz}, 1 \mathrm{H} ; 1 \mathrm{H}_{\mathrm{Bn}}\right), 4.86(\mathrm{~d}$, $\left.J=11.0 \mathrm{~Hz}, 1 \mathrm{H} ; 1 \mathrm{H}_{\mathrm{Bn}}\right), 4.79\left(\mathrm{~s}, 2 \mathrm{H} ; 2 \mathrm{H}_{\mathrm{Bn}}\right), 4.75(\mathrm{~d}, J=11.0 \mathrm{~Hz}$, $\left.1 \mathrm{H} ; 1 \mathrm{H}_{\mathrm{Bn}}\right), 4.73\left(\mathrm{~d}, J=11.0 \mathrm{~Hz}, 1 \mathrm{H} ; 1 \mathrm{H}_{\mathrm{Bn}}\right), 4.72(\mathrm{~d}, J=11.0 \mathrm{~Hz}$, $\left.1 \mathrm{H} ; 1 \mathrm{H}_{\mathrm{Bn}}\right), 4.69\left(\mathrm{~d}, J=1.5 \mathrm{~Hz}, 1 \mathrm{H} ; \mathrm{H}_{1}\right), 4.62-4.47\left(\mathrm{~m}, 7 \mathrm{H} ; 7 \mathrm{H}_{\mathrm{Bn}}\right)$, $4.24\left(\mathrm{dd}, J=3.8 \mathrm{~Hz}\right.$ and $\left.9.4 \mathrm{~Hz}, 1 \mathrm{H} ; \mathrm{H}_{3}\right), 4.01-4.67(\mathrm{~m}, 15 \mathrm{H}$; $\mathrm{H}_{4 \mathrm{~A}}, \mathrm{H}_{5 \mathrm{~A}}, 2 \mathrm{H}_{6 \mathrm{~A}}, \mathrm{H}_{3 \mathrm{~B}}, \mathrm{H}_{4 \mathrm{~B}}, \mathrm{H}_{5 \mathrm{~B}}, 2 \mathrm{H}_{6 \mathrm{~B}}, \mathrm{H}_{3 \mathrm{C}}, \mathrm{H}_{4 \mathrm{C}}, \mathrm{H}_{5 \mathrm{C}}, 2 \mathrm{H}_{6 \mathrm{C}}$ and $\mathrm{H}_{7}$ ), 3.56-5.51 (m, 1H; $\left.\mathrm{H}_{7}\right), 3.33-3.27\left(\mathrm{~m}, 2 \mathrm{H} ; 2 \mathrm{H}_{8}\right), 2.74-2.61(\mathrm{~m}, 4 \mathrm{H}$; $\left.2 \times-\mathrm{CH}_{2 \mathrm{lev}}\right), 2.20\left(\mathrm{~s}, 3 \mathrm{H} ; \mathrm{CH}_{3 \mathrm{lev}}\right), 2.15\left(\mathrm{~s}, 3 \mathrm{H} ;-\mathrm{OOCCH}_{3}\right), 2.13(\mathrm{~s}$, $3 \mathrm{H}$; $\left.-\mathrm{OOCCH}_{3}\right) ;{ }^{13} \mathrm{C} \mathrm{NMR}\left(125 \mathrm{MHz}, \mathrm{CDCl}_{3}\right): d=208.1(\mathrm{C}=\mathrm{O})$, $174.5(\mathrm{C}=\mathrm{O}), 172.6(\mathrm{C}=\mathrm{O}), 172.4(\mathrm{C}=\mathrm{O}), 141.0\left(\mathrm{C}_{\mathrm{Ar}}\right), 140.7\left(\mathrm{C}_{\mathrm{Ar}}\right)$, $140.5\left(\mathrm{C}_{\mathrm{Ar}}\right), 140.3\left(\mathrm{C}_{\mathrm{Ar}}\right), 140.2\left(\mathrm{C}_{\mathrm{Ar}}\right), 139.9\left(\mathrm{C}_{\mathrm{Ar}}\right), 130.7\left(\mathrm{C}_{\mathrm{Ar}}\right), 130.7$ $\left(\mathrm{C}_{\mathrm{Ar}}\right), 130.6\left(\mathrm{C}_{\mathrm{Ar}}\right), 130.5\left(\mathrm{C}_{\mathrm{Ar}}\right), 130.4\left(\mathrm{C}_{\mathrm{Ar}}\right), 130.3\left(\mathrm{C}_{\mathrm{Ar}}\right), 130.2\left(\mathrm{C}_{\mathrm{Ar}}\right)$, $130.1\left(\mathrm{C}_{\mathrm{Ar}}\right), 130.0\left(\mathrm{C}_{\mathrm{Ar}}\right), 129.8\left(\mathrm{C}_{\mathrm{Ar}}\right), 129.7\left(\mathrm{C}_{\mathrm{Ar}}\right), 102.4\left(\mathrm{C}_{1}\right), 100.9$ $\left(\mathrm{C}_{1}\right), 99.4\left(\mathrm{C}_{1}\right), 80.2,80.0,76.7,76.5,76.3,75.7,75.7,74.6,74.2$, 74.1, 73.8, 73.6, 71.1, 71.0, 70.8, 70.7, 69.0, $67.6\left(\mathrm{C}_{2 \mathrm{~A}}+\mathrm{C}_{3 \mathrm{~A}}+\right.$ $\mathrm{C}_{4 \mathrm{~A}}+\mathrm{C}_{5 \mathrm{~A}}+\mathrm{C}_{6 \mathrm{~A}}, \mathrm{C}_{2 \mathrm{~B}}+\mathrm{C}_{3 \mathrm{~B}}+\mathrm{C}_{4 \mathrm{~B}}+\mathrm{C}_{5 \mathrm{~B}}+\mathrm{C}_{6 \mathrm{~B}}+\mathrm{C}_{2 \mathrm{C}}+\mathrm{C}_{3 \mathrm{C}}+\mathrm{C}_{4 \mathrm{C}}+$ $\left.\mathrm{C}_{5 \mathrm{C}}+\mathrm{C}_{6 \mathrm{C}}\right) 52.5\left(\mathrm{C}_{8}\right), 40.1\left(\mathrm{CH}_{2 \mathrm{lev}}\right), 32.0\left(\mathrm{CH}_{2 \mathrm{lev}}\right), 30.3\left(\mathrm{CH}_{3 \mathrm{lev}}\right), 23.4$ $\left(\mathrm{OCOCH}_{3}\right), 23.3\left(\mathrm{OCOCH}_{3}\right)$; ESI-MS for $\mathrm{C}_{78} \mathrm{H}_{87} \mathrm{~N}_{3} \mathrm{O}_{20}$; calcd: 1385,6 $\mathrm{M}^{+}$; found: $1408.6[\mathrm{M}+\mathrm{Na}]^{+}$and $1424.4[\mathrm{M}+\mathrm{K}]^{+}$.

\section{Synthesis of 2-azidoethyl $O$-(2-O-acetyl-3,4,6-tri- $O$-benzyl-} $a$-D-mannopyranosyl-(1 $\rightarrow 2)-O$-[2-O-acetyl-3,4,6-tri- $O$ -

benzyl- $a$-D-mannopyranosyl-( $\rightarrow 6$ ]-4- $O$-benzyl- 3$O$-(4-methoxybenzyl)- $a$-D-mannopyranoside (12)

Mannose derivative 7 ( $49 \mathrm{mg}, 0.107 \mathrm{mmol}$ ), and the glycosyl donor 13 (163 mg, $0.278 \mathrm{mmol}$ ) were dissolved in dry $\mathrm{CH}_{2} \mathrm{Cl}_{2}(2 \mathrm{~mL})$ in the presence of $4 \AA$ molecular sieves. The mixture was stirred during 2 hours at room temperature under argon atmosphere. Then, the system was cooled at $-20{ }^{\circ} \mathrm{C}$, NIS (63 $\left.\mathrm{mg}, 0.278 \mathrm{mmol}\right)$ and $\mathrm{TfOH}(2.5 \mathrm{lL}, 0.026 \mathrm{mmol})$ were added and the mixture was stirred during $20 \mathrm{~min}$. The reaction was monitored by TLC (toluene- $\mathrm{MeOH}, 9: 1$ ) and when it was completed, $\mathrm{NaHCO}_{3}$ sat. (50 lL) was added to quench the TfOH. The reaction mixture was diluted with $\mathrm{CH}_{2} \mathrm{Cl}_{2}(6 \mathrm{~mL})$, filtered over a pad of Celite, washed with $\mathrm{Na}_{2} \mathrm{~S}_{2} \mathrm{O}_{3}$ sat., dried over $\mathrm{MgSO}_{4}$ and the solvent was removed under vacuum. The residue was purified by flash chromatography on silica gel (hexane : AcOEt, $7: 1$ ) to give compound 12 as an oil (88 mg, 70\%). $\left[a \mathbb{d}^{20}=+17.05\left(c=1.00\right.\right.$ in $\left.\mathrm{CHCl}_{3}\right) ;{ }^{1} \mathrm{H}$ NMR $\left(500 \mathrm{MHz}, \mathrm{CDCl}_{3}\right): d=7.32-7.21\left(\mathrm{~m}, 32 \mathrm{H} ; 18 \mathrm{H}_{\mathrm{ArBn}}+2 \mathrm{H}_{\mathrm{ArPMB}}\right)$, $7.16-7.13\left(\mathrm{~m}, 2 \mathrm{H} ; 2 \mathrm{H}_{\mathrm{ArBn}}\right), 7.12-7.08\left(\mathrm{~m}, 2 \mathrm{H} ; 2 \mathrm{H}_{\mathrm{ArBn}}\right), 6.80(\mathrm{~d}, J=$ $\left.9.0 \mathrm{~Hz}, 2 \mathrm{H} ; 2 \mathrm{H}_{\mathrm{ArPMB}}\right), 5.51\left(\mathrm{dd}, J=3.5 \mathrm{~Hz}\right.$ and $\left.1.5 \mathrm{~Hz}, 1 \mathrm{H} ; \mathrm{H}_{2 \mathrm{~B}}\right)$, $5.34\left(\mathrm{dd}, J=2.0 \mathrm{~Hz}\right.$ and $\left.3.0 \mathrm{~Hz}, 1 \mathrm{H} ; \mathrm{H}_{2 \mathrm{C}}\right), 4.99(\mathrm{~d}, J=1.5 \mathrm{~Hz}, 1 \mathrm{H}$; $\left.\mathrm{H}_{1 \mathrm{~B}}\right), 4.89\left(\mathrm{~d}, J=1.5 \mathrm{~Hz}, 1 \mathrm{H} ; \mathrm{H}_{1 \mathrm{C}}\right), 4.82\left(\mathrm{~d}, J=11.0 \mathrm{~Hz}, 1 \mathrm{H} ; \mathrm{H}_{\mathrm{Bn}}\right)$, $4.81\left(\mathrm{~d}, J=11.0 \mathrm{~Hz}, 2 \mathrm{H} ; 2 \mathrm{H}_{\mathrm{Bn}}\right), 4.81\left(\mathrm{~d}, J=1.5 \mathrm{~Hz}, 1 \mathrm{H} ; \mathrm{H}_{1 \mathrm{~A}}\right), 4.79$ $\left(\mathrm{d}, J=11.0 \mathrm{~Hz}, 1 \mathrm{H}, \mathrm{H}_{\mathrm{Bn}}\right), 4.61\left(\mathrm{~d}, J=11.0 \mathrm{~Hz}, 1 \mathrm{H} ; \mathrm{H}_{\mathrm{Bn}}\right), 4.61(\mathrm{~d}$, $\left.J=11.0 \mathrm{~Hz}, 1 \mathrm{H} ; \mathrm{H}_{\mathrm{Bn}}\right), 4.56\left(\mathrm{~s}, 2 \mathrm{H} ; 2 \mathrm{H}_{\mathrm{Bn}}\right), 4.50(\mathrm{~d}, J=11.0 \mathrm{~Hz}, 1 \mathrm{H}$; $\left.\mathrm{H}_{\mathrm{Bn}}\right), 4.49\left(\mathrm{~d}, 1 \mathrm{H}, J=11.0 \mathrm{~Hz}, 1 \mathrm{H} ; \mathrm{H}_{\mathrm{Bn}}\right), 4.46-4.40\left(\mathrm{~m}, 5 \mathrm{H}, 5 \mathrm{H}_{\mathrm{Bn}}\right)$, $3.95\left(\mathrm{dd}, 1 \mathrm{H} J=3.2 \mathrm{~Hz}\right.$ and $\left.9.3 \mathrm{~Hz}, 1 \mathrm{H} ; \mathrm{H}_{3 \mathrm{~A}}\right), 3.94-3.60(\mathrm{~m}, 15 \mathrm{H}$; $\mathrm{H}_{2 \mathrm{~A}}, \mathrm{H}_{4 \mathrm{~A}}, \mathrm{H}_{5 \mathrm{~A}}, 2 \mathrm{H}_{6 \mathrm{~A}}, \mathrm{H}_{3 \mathrm{~B}}, \mathrm{H}_{4 \mathrm{~B}}, \mathrm{H}_{5 \mathrm{~B}}, 2 \mathrm{H}_{6 \mathrm{~B}}, \mathrm{H}_{3 \mathrm{C}}, \mathrm{H}_{4 \mathrm{C}}, \mathrm{H}_{5 \mathrm{C}}$ and $2 \mathrm{H}_{6 \mathrm{C}}$ ), $3.76\left(\mathrm{~s}, 3 \mathrm{H},-\mathrm{OCH}_{3}\right), 3.52\left(\mathrm{t}, J=9.3 \mathrm{~Hz}, 1 \mathrm{H} ; \mathrm{H}_{7}\right), 3.32-3.28(\mathrm{~m}$, $\left.1 \mathrm{H} ; \mathrm{H}_{7}\right), 3.20-3.11\left(\mathrm{~m}, 2 \mathrm{H} ; 2 \mathrm{H}_{8}\right), 2.10\left(\mathrm{~s}, 3 \mathrm{H} ;-\mathrm{OOCCH}_{3}\right), 2.09(\mathrm{~s}$, $3 \mathrm{H}$; $\left.-\mathrm{OOCCH}_{3}\right) ;{ }^{13} \mathrm{C} \mathrm{NMR}\left(100 \mathrm{MHz}, \mathrm{CDCl}_{3}\right): d=170.3(\mathrm{C}=\mathrm{O})$, $170.07(\mathrm{C}=\mathrm{O}), 159.2\left(\mathrm{C}_{\mathrm{Ar}}\right), 138.6\left(\mathrm{C}_{\mathrm{Ar}}\right), 138.4\left(\mathrm{C}_{\mathrm{Ar}}\right), 138.3\left(\mathrm{C}_{\mathrm{Ar}}\right)$, $138.2\left(\mathrm{C}_{\mathrm{Ar}}\right), 138.0\left(\mathrm{C}_{\mathrm{Ar}}\right), 137.9\left(\mathrm{C}_{\mathrm{Ar}}\right), 130.3\left(\mathrm{C}_{\mathrm{Ar}}\right), 129.3\left(\mathrm{C}_{\mathrm{Ar}}\right), 128.4$ $\left(\mathrm{C}_{\mathrm{Ar}}\right), 128.3\left(\mathrm{C}_{\mathrm{Ar}}\right), 128.3\left(\mathrm{C}_{\mathrm{Ar}}\right), 128.2\left(\mathrm{C}_{\mathrm{Ar}}\right), 128.1\left(\mathrm{C}_{\mathrm{Ar}}\right), 128.0\left(\mathrm{C}_{\mathrm{Ar}}\right)$, 128.0 $\left(\mathrm{C}_{\mathrm{Ar}}\right), 127.9\left(\mathrm{C}_{\mathrm{Ar}}\right), 127.8\left(\mathrm{C}_{\mathrm{Ar}}\right), 127.6\left(\mathrm{C}_{\mathrm{Ar}}\right), 127.6\left(\mathrm{C}_{\mathrm{Ar}}\right), 127.5$ $\left(\mathrm{C}_{\mathrm{Ar}}\right), 113.8\left(\mathrm{C}_{\mathrm{Ar}}\right), 99.8\left(\mathrm{C}_{1}\right), 98.7\left(\mathrm{C}_{1}\right), 97.1\left(\mathrm{C}_{1}\right), 79.4,78.1,78.0$, 
77.2, 75.2, 75.1, 74.9, 74.4, 73.5, 73.4, 71.9, 71.5, 71.4, 70.8, 69.2, 68.7, 68.5, 68.5, 66.3, $55.2\left(\mathrm{C}_{2 \mathrm{~A}}+\mathrm{C}_{3 \mathrm{~A}}+\mathrm{C}_{4 \mathrm{~A}}+\mathrm{C}_{5 \mathrm{~A}}+\mathrm{C}_{6 \mathrm{~A}}+\mathrm{C}_{2 \mathrm{~B}}+\right.$ $\left.\mathrm{C}_{3 \mathrm{~B}}+\mathrm{C}_{4 \mathrm{~B}}+\mathrm{C}_{5 \mathrm{~B}}+\mathrm{C}_{6 \mathrm{~B}}+\mathrm{C}_{2 \mathrm{C}}+\mathrm{C}_{3 \mathrm{C}}+\mathrm{C}_{4 \mathrm{C}}+\mathrm{C}_{5 \mathrm{C}}+\mathrm{C}_{6 \mathrm{C}}+\mathrm{C}_{7}\right), 50.3$ $\left(\mathrm{C}_{8}\right), 21.1\left(\mathrm{OCOCH}_{3}\right), 21.1\left(\mathrm{OCOCH}_{3}\right)$; ESI-MS for $\mathrm{C}_{81} \mathrm{H}_{89} \mathrm{~N}_{3} \mathrm{O}_{19}$; calcd: $1407.6 \mathrm{M}^{+}$; found: $1446.6[\mathrm{M}+\mathrm{K}]^{+}$.

\section{Synthesis of 2-aminoethyl $O$ - $a$-D-mannopyranosyl $(1 \rightarrow 2)[O$ - $a$-D- mannopyranosyl $(1 \rightarrow 6)]$ - $a$-D-mannopyranoside $(1)$}

The protected trisaccharide 12 (70 $\mathrm{mg}, 0.06 \mathrm{mmol})$ was dissolved in dry $\mathrm{MeOH}(1 \mathrm{~mL})$ and $\mathrm{NaOMe}$ solution $(1 \mathrm{M}$ in $\mathrm{MeOH})(60 \mathrm{ll}$, $0.06 \mathrm{mmol}$ ) was added. The reaction mixture was stirred at room temperature for $30 \mathrm{~min}$. Then, the mixture was neutralized with Amberlite IR 120 resin, filtered and the solvent was removed under vacuum. The white solid was dissolved in $\mathrm{MeOH}(3 \mathrm{~mL}), \mathrm{Pd}-\mathrm{C}$ $10 \%$ (cat.) was added and the reaction mixture was hydrogenated under $\mathrm{H}_{2}$ (1 bar) until reduction was complete (monitored by TLC $i$-PrOH : $\left.\mathrm{H}_{2} \mathrm{O} 7: 3+1 \% \mathrm{AcOH}\right)$ to give trisaccharide $\mathbf{1}$ as a white solid (32 mg, $98 \%$ over two steps). $[a]^{20}=+78.2\left(c=0.50\right.$ in $\left.\mathrm{H}_{2} \mathrm{O}\right)$; ${ }^{1} \mathrm{H}$ NMR $\left(500 \mathrm{MHz}, \mathrm{D}_{2} \mathrm{O}\right): d=5.10\left(\mathrm{~s}, 1 \mathrm{H} ; \mathrm{H}_{1 \mathrm{~A}}\right), 5.00(\mathrm{~s}, 1 \mathrm{H}$; $\left.\mathrm{H}_{1 \mathrm{C}}\right), 4.90\left(\mathrm{~s}, 1 \mathrm{H} ; \mathrm{H}_{1 \mathrm{~B}}\right), 4.06\left(\mathrm{~m}, 1 \mathrm{H} ; \mathrm{H}_{2 \mathrm{C}}\right), 3.99\left(\mathrm{~m}, 1 \mathrm{H} ; \mathrm{H}_{2 \mathrm{~A}}\right), 3.97$ $\left(\mathrm{m}, 1 \mathrm{H} ; \mathrm{H}_{6 \mathrm{~A}}\right), 3.96\left(\mathrm{~m}, 1 \mathrm{H} ; \mathrm{H}_{2 \mathrm{~B}}\right), 3.91\left(\mathrm{~m}, 1 \mathrm{H} ; \mathrm{H}_{3 \mathrm{~A}}\right), 3.90(\mathrm{~m}, 1 \mathrm{H}$;

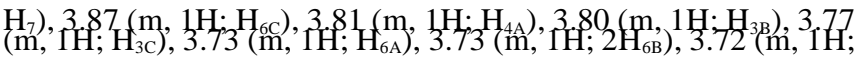

$\left.\mathrm{H}_{5 \mathrm{~A}}\right), 3.71\left(\mathrm{~m}, 1 \mathrm{H} ; \mathrm{H}_{5 \mathrm{C}}\right), 3.69\left(\mathrm{~m}, 1 \mathrm{H} ; \mathrm{H}_{6 \mathrm{C}}\right), 3.65\left(\mathrm{~m}, 1 \mathrm{H} ; \mathrm{H}_{7}\right), 3.65$ $\left(\mathrm{m}, 1 \mathrm{H} ; \mathrm{H}_{5 \mathrm{~B}}\right), 3.64\left(\mathrm{~m}, 1 \mathrm{H} ; \mathrm{H}_{4 \mathrm{~B}}\right), 3.61\left(\mathrm{~m}, 1 \mathrm{H} ; \mathrm{H}_{4 \mathrm{C}}\right), 3.17(\mathrm{~m}, 1 \mathrm{H}$; $\left.2 \mathrm{H}_{8}\right) \cdot{ }^{13} \mathrm{C}$ NMR $\left(125 \mathrm{MHz}, \mathrm{D}_{2} \mathrm{O}\right): d=102.4\left(\mathrm{C}_{1 \mathrm{C}}\right), 99.5\left(\mathrm{C}_{1 \mathrm{~B}}\right), 98.4$ $\left(\mathrm{C}_{1 \mathrm{~A}}\right), 78.7\left(\mathrm{C}_{2 \mathrm{~A}}\right), 73.3\left(\mathrm{C}_{5 \mathrm{C}}\right), 72.8\left(\mathrm{C}_{5 \mathrm{~B}}\right), 70.5\left(\mathrm{C}_{3 \mathrm{~B}}\right), 70.5\left(\mathrm{C}_{3 \mathrm{C}}\right), 71.4$ $\left(\mathrm{C}_{5 \mathrm{~A}}\right), 70.1\left(\mathrm{C}_{3 \mathrm{~A}}\right), 69.9\left(\mathrm{C}_{2 \mathrm{C}}\right), 69.9\left(\mathrm{C}_{2 \mathrm{~B}}\right), 66.7\left(\mathrm{C}_{4 \mathrm{C}}\right), 66.6\left(\mathrm{C}_{4 \mathrm{~B}}\right), 66.4$ $\left(\mathrm{C}_{4 \mathrm{~A}}\right), 65.1\left(\mathrm{C}_{6 \mathrm{~A}}\right), 64.5\left(\mathrm{C}_{7}\right), 61.0\left(\mathrm{C}_{6 \mathrm{C}}\right), 60.9\left(\mathrm{C}_{6 \mathrm{~B}}\right), 39.1\left(\mathrm{C}_{8}\right)$.

Synthesis of 2-aminoethyl $O$ - $a$-D-mannopyranosyl $(1 \rightarrow 3)[O-a$-Dmannopyranosyl $(1 \rightarrow 6)$ ]- $a$-D-mannopyranoside $(2)$

The protected trisaccharide $\mathbf{1 1}$ (70 $\mathrm{mg}, 0.05 \mathrm{mmol}$ ) was dissolved in dry $\mathrm{MeOH}(2 \mathrm{~mL})$ and $\mathrm{NaOMe}$ solution (1 M in $\mathrm{MeOH})(5011$, $0.05 \mathrm{mmol}$ ) was added. The reaction mixture was stirred at room temperature for $30 \mathrm{~min}$. Then, the mixture was neutralized with Amberlite IR 120 resin, filtered and the solvent was removed under vacuum. The white solid was dissolved in $\mathrm{MeOH}(3 \mathrm{~mL}), \mathrm{Pd}-\mathrm{C}$ $10 \%$ (cat.) was added and the reaction mixture was hydrogenated under $\mathrm{H}_{2}$ (1 bar) until reduction was complete (monitored by TLC $i$ - $\left.\mathrm{PrOH}: \mathrm{H}_{2} \mathrm{O} 7: 3+1 \% \mathrm{AcOH}\right)$ to give trisaccharide 2 as a white solid (27 mg, 97\% over two steps). $[a]^{20}=+84.0\left(c=0.50\right.$ in $\left.\mathrm{H}_{2} \mathrm{O}\right)$; ${ }^{1} \mathrm{H}$ NMR $\left(500 \mathrm{MHz}, \mathrm{D}_{2} \mathrm{O}\right): d=5.10\left(\mathrm{~m}, 1 \mathrm{H} ; \mathrm{H}_{1 \mathrm{~B}}\right), 4.90(\mathrm{~s}, 1 \mathrm{H}$; $\left.\mathrm{H}_{1 \mathrm{D}}\right), 4.85\left(\mathrm{~s}, 1 \mathrm{H} ; \mathrm{H}_{1 \mathrm{~A}}\right), 4.15\left(\mathrm{~m}, 1 \mathrm{H} ; \mathrm{H}_{2 \mathrm{~A}}\right), 4.06\left(\mathrm{~m}, 1 \mathrm{H} ; \mathrm{H}_{2 \mathrm{~B}}\right), 4.00$ $\left(\mathrm{m}, 1 \mathrm{H} ; \mathrm{H}_{6 \mathrm{~A}}\right), 3.98\left(\mathrm{~m}, 1 \mathrm{H} ; \mathrm{H}_{2 \mathrm{D}}\right), 3.96\left(\mathrm{~m}, 1 \mathrm{H} ; \mathrm{H}_{7}\right), 3.93(\mathrm{~m}, 1 \mathrm{H}$; $\left.\mathrm{H}_{3 \mathrm{~A}}\right), 3.92\left(\mathrm{~m}, 1 \mathrm{H} ; \mathrm{H}_{4 \mathrm{~A}}\right), 3.89\left(\mathrm{~m}, 1 \mathrm{H} ; \mathrm{H}_{6 \mathrm{~A}}\right), 3.87\left(\mathrm{~m}, 1 \mathrm{H} ; \mathrm{H}_{3 \mathrm{~B}}\right), 3.82$ $\left(\mathrm{m}, 1 \mathrm{H} ; \mathrm{H}_{3 \mathrm{D}}\right), 3.79\left(\mathrm{~m}, 1 \mathrm{H} ; \mathrm{H}_{5 \mathrm{~A}}\right), 3.77\left(\mathrm{~m}, 1 \mathrm{H} ; \mathrm{H}_{5 \mathrm{~B}}\right), 3.75(\mathrm{~m}, 1 \mathrm{H}$; $\left.\mathrm{H}_{6 \mathrm{~A}}\right), 3.75\left(\mathrm{~m}, 1 \mathrm{H} ; \mathrm{H}_{6 \mathrm{D}}\right), 3.70\left(\mathrm{~m}, 1 \mathrm{H} ; \mathrm{H}_{6 \mathrm{~A}}\right), 3.70\left(\mathrm{~m}, 1 \mathrm{H} ; \mathrm{H}_{7}\right), 3.67$ $\left(\mathrm{m}, 1 \mathrm{H} ; \mathrm{H}_{4 \mathrm{D}}\right), 3.66\left(\mathrm{~m}, 1 \mathrm{H} ; \mathrm{H}_{5 \mathrm{D}}\right), 3.61\left(\mathrm{~m}, 1 \mathrm{H} ; \mathrm{H}_{4 \mathrm{~B}}\right), 3.24(\mathrm{~m}, 1 \mathrm{H}$; $\left.2 \mathrm{H}_{8}\right) ;{ }^{13} \mathrm{C}$ NMR $\left(125 \mathrm{MHz}, \mathrm{D}_{2} \mathrm{O}\right): d=102.4\left(\mathrm{C}_{1 \mathrm{~B}}\right), 99.8\left(\mathrm{C}_{1 \mathrm{~A}}\right), 99.3$ $\left(\mathrm{C}_{1 \mathrm{D}}\right), 78.5\left(\mathrm{C}_{3 \mathrm{~A}}\right), 73.4\left(\mathrm{C}_{5 \mathrm{~B}}\right), 72.6\left(\mathrm{C}_{5 \mathrm{D}}\right), 71.1\left(\mathrm{C}_{5 \mathrm{~A}}\right), 70.7\left(\mathrm{C}_{3 \mathrm{D}}\right), 70.3$ $\left(\mathrm{C}_{3 \mathrm{~B}}\right), 70.1\left(\mathrm{C}_{2 \mathrm{~B}}\right), 70.0\left(\mathrm{C}_{2 \mathrm{D}}\right), 69.4\left(\mathrm{C}_{2 \mathrm{~A}}\right), 66.6\left(\mathrm{C}_{4 \mathrm{D}}\right), 66.6\left(\mathrm{C}_{4 \mathrm{~B}}\right), 65.3$ $\left(\mathrm{C}_{4 \mathrm{~A}}\right), 65.2\left(\mathrm{C}_{6 \mathrm{~A}}\right), 63.6\left(\mathrm{C}_{7}\right), 60.8\left(\mathrm{C}_{6 \mathrm{D}}\right), 60.8\left(\mathrm{C}_{6 \mathrm{~B}}\right), 39.1\left(\mathrm{C}_{8}\right)$.

\section{Computational studies}

All calculations were performed on a Silicon Graphics Octane workstation (R12000, $300 \mathrm{MHz}$ ) using the SYBYL 6.9 program suite. ${ }^{26}$ The starting coordinate of human DC-SIGN was taken from the Protein Data Bank with code 1k9i. ${ }^{12}$ The structure was edited to contain only one protein monomer together with calcium ions, protein hydrogen atoms were added, the partial charges were calculated using AMBER $^{27,28}$ procedure as implemented in SYBYL and the calcium ions were given a charge of $(+2)$. Atom types and charges for oligosaccharides were defined using the PIM parameters developed for carbohydrates. ${ }^{29}$ All ligand structures were obtained from different protein complex: dimannoside Mana1,2Man (ManC-ManA) from $1 \mathrm{i} 3 \mathrm{~h} ;{ }^{30}$ dimannosides Mana1,3Man (ManD-ManA) and Mana1,6Man (ManBManA), trimannoside Mana1,2[Mana1,6]Man, (ManC-ManAManB) were built from Mana1,2Man using the Sketch module of SYBYL; and trimannoside Mana1,3[Mana1,6]Man (ManDManA-ManB) was built and fitted into DC-SIGN using the correspond ligand $\left(\mathrm{GlcNAc}_{2} \mathrm{Man}_{3}\right)$ from $1 \mathrm{k} 9 \mathrm{i}$.

The nomenclature used for the theoretical complex (1d13, $1 \mathrm{~d} 12,1 \mathrm{~d} 16,1 \mathrm{t} 26,1 \mathrm{t} 36)$ does mention if it is a dimannoside (d) a trimannoside (t) and the glycoside bond $1 \rightarrow 3$, $1-2,1-6$ in Mana1,3Man, Mana1,2Man and Mana1,6Man, respectively and, $1 \rightarrow 2-6 \leftarrow 1,1 \rightarrow 3-6 \leftrightarrow 1$ in the trisaccharide Mana1,2[Mana1,6]Man and Mana1,3[Mana1,6]Man. The dihedral angles $U, w$ and $x$ are defined, following IUPAC definition, as O5-C1-O1- $\mathrm{C}_{x} \mathbf{j}, \mathrm{C} 1-\mathrm{O} 1-\mathrm{C}_{x} \mathbf{j}-\mathrm{C}_{x+1} \mathbf{j}$ and O5-C5-C6-O6 respectively, where $\mathrm{C}_{x}$ jand $\mathrm{C}_{x+1}$ are the aglyconic atoms. Fora-D-Manp-

(1-6)-a-D-Manp, the $U$ is defined as $\mathrm{O} 5-\mathrm{C} 1-\mathrm{O} 1-\mathrm{C}^{\mathbf{j}}, w \mathrm{C} 1-\mathrm{O} 1-$ $\mathrm{C}^{\mathbf{j}}-\mathrm{C}^{\mathbf{j}}$ and $x \mathrm{O} 1-\mathrm{C}^{\mathbf{j}}-\mathrm{C}^{\mathbf{j}}-\mathrm{OR}^{\mathbf{j}}$ where $\mathrm{OR}^{\mathbf{j}}$ is the endocyclic ring oxygen.

To build the complexes, the ligands were first manually positioned within the binding pocket of the protein taking into account the experimental data about the binding of $1 \mathrm{k} 9 \mathrm{i}$. Two binding modes were examined for each of the disaccharides Mana1,6Man and Mana1,2Man: one refers to the primary binding site (complexes $1 \mathrm{~d} 12$ and $1 \mathrm{~d} 16$, respectively), which corresponds to the glycosidic bonds at the 3-position (Mana1,3Man in the pentasaccharide $\mathrm{GlcNAc}_{2} \mathrm{Man}_{3}$; ManD-ManA), and the other involves the secondary binding site (complexes $2 \mathrm{~d} 12$ and $2 \mathrm{~d} 16$, respectively), corresponding to the glycosidic bonds at 6 position (Mana1,6Man in the pentasaccharide $\mathrm{GlcNAc}_{2} \mathrm{Man}_{3}$ : ManB-ManA). Regarding the disaccharide Mana1,2Man, it was only considered the primary binding site (1d13). Subsequent energy minimization was performed using the AMBER99 force field with geometry optimization of the sugar and the side chains of the protein. Energy minimizations were carried out using the Conjugate Gradient procedure until a gradient deviation of $0.005 \mathrm{kcal} \mathrm{mol}^{-1} \AA^{-1}$ was attained. A distance-dependent dielectric constant was used in the calculations.

These complexes were used as input structure for docking studies using FlexiDock command in the Biopolymer module. FlexiDock software performs flexible docking of conformationally flexible ligands into receptor binding sites and provides control of ligand binding characteristics, taking into account rigid, partially flexible, or fully flexible receptor side chains. FlexiDock incorporates the Van der Waals, electrostatic, torsional and constraint energy terms of the Tripos force field, and it uses a genetic algorithm to determine the optimum ligand geometry. Genetic algorithms $^{31}$ (GA) borrow methodology and terminology from biological (or Darwinian) evolution, in which they are an iterative process where the most-fit members of a population will have the 
best chance of propagating themselves into future generations. During the flexible docking analysis the residues involved in the binding site (sphere of $7 \AA$ around the ligand), and the ligands were considered flexible. The default SYBYL FlexiDock parameters were utilized in all cases. Five runs of FlexiDock were performed searching for the different binding modes with iterations set to 500-1000 generations per gene, where gene is the number of rotatable bonds plus six, obtaining a series of model complexes.

The output complexes of FlexiDock were analyzed on the basis of the score provided by FlexiDock, the dihedral angles $U, w, x$ and the distances of key residues. The conformations with typical dihedral angles of each glycosidic bond at positions 2, 3, and 6 were clustered and the rest of the non-typical conformations were eliminated. A member of each family was energy minimized. These output complexes were again optimized until gradient $0.01 \mathrm{kcal}$ $\mathrm{mol}^{-1} \AA^{-1}$ using the above mentioned conditions, the conformation with the lowest score and fulfilling the experimental requirements being chosen. The binding free energies $\left(D G_{\text {bind }}\right.$ ) of all disaccharides and trisaccharides complexes were calculated with the Structural Thermodynamics Calculations V4.3 (STC) program $^{32}$ in order to predict the interaction energy of each complex. The STC program calculates the $\mathrm{D} G_{\text {bind }}$ from a parameterization (per $\AA^{2}$ of polar and nonpolar ASA) of the heat capacity, enthalpy, and solvation entropy obtained from a global fit of structural and thermodynamic database of globular proteins. Carbohydrateprotein interactions were calculated with the LPC program. ${ }^{33}$ As selection criteria used to identify $\mathrm{C}-\mathrm{H}-\mathrm{p}$ interaction, we applied those used by Brandl ${ }^{34}$ and Kerzmann. ${ }^{35}$ Fig. 7 shows the three values $d_{\mathrm{cx}}, a_{\mathrm{chx}}$ and $d_{\mathrm{HpX}}$. The limits are $d_{\mathrm{cx}}<4.5 \AA, a_{\mathrm{chx}}>110^{\circ}$ and $d_{\mathrm{HpX}}<2.0 \AA$.

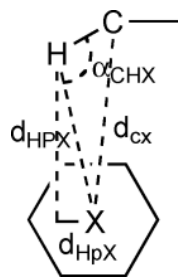

Fig. 7 Geometry of the $\mathrm{C}-\mathrm{H} \cdots$ p interaction.

\section{NMR}

NMR sample preparation. NMR experiments were recorded in AVANCE Bruker instruments operating at $500.13 \mathrm{MHz}$, at $288 \mathrm{~K}$. Samples of free $\mathbf{1}$ and $\mathbf{2}$ were prepared in $150 \mathrm{mM} \mathrm{NaCl}$, $25 \mathrm{mMd}$-TRIS $\left(\mathrm{pH}^{*}=8.1\right)$ in $\mathrm{D}_{2} \mathrm{O}$ after three cycles of deuterium exchange by evaporation and resolution of the trisaccharide in $\mathrm{D}_{2} \mathrm{O}$. The samples in the presence of DC-SIGN EC were prepared using $2 \mathrm{mM}$ of carbohydrate and $401 \mathrm{M}$ of lectin, assuming a monomeric state, in $\mathrm{D}_{2} \mathrm{O}\left(150 \mathrm{mM} \mathrm{NaCl}, 25 \mathrm{mM}\right.$ d-TRIS, $\mathrm{pH}^{*}=$ 8.1).

NMR experiments were performed using manufacturer pulse sequences: dqf-COSY, ${ }^{36}$ TOCSY ${ }^{37}$ NOESY, ${ }^{38}$ ROESY, ${ }^{39}$ and $\mathrm{HSQC}^{40}$ implemented with z-pulsed field gradients when possible, and acquired using time proportional phase incrementation mode. ${ }^{41}$ The size of the acquisition data matrix for homonuclear experiments was typically of $2 \mathrm{k} \times 512$ in F2 and F1 dimensions, respectively. Data were processed using manufacturer software, raw data were multiplied by shifted square sine window function prior to Fourier transform, and the baseline was corrected using polynomial fitting.

STD experiments were performed at $278 \mathrm{~K}$ using watergate solvent suppression at $0.5,0.75,1.0,1.25,1.5$ and $2.0 \mathrm{~s}$ saturation times using a train of Gaussian shaped pulses of $49 \mathrm{~ms}$ and $100-60 \mathrm{~Hz}$ power spaced by $1.0 \mathrm{~ms}$ delays. ${ }^{23} \mathrm{On}-$ resonance irradiation was performed at $0.9 \mathrm{ppm}$, appropriate blank experiments were also performed to assure the absence of direct irradiation on the ligand.

\section{DC-SIGN EC expression and purification}

Plasmids pET30b (Novagen) containing cDNA encoding the EctoDomain ECD (corresponding to amino acids 66-404) of DC-SIGN were used for overproduction as described previously. ${ }^{5}$ Proteins produced in inclusion bodies have been refolded as already described. ${ }^{42}$ Purification of functional DC-SIGN proteins were achieved by an affinity chromatography on Mannan-agarose column (Sigma) equilibrated in $25 \mathrm{mM}$ Tris- $\mathrm{HCl} \mathrm{pH}$ 7.8, $150 \mathrm{mM}$ $\mathrm{NaCl}, 4 \mathrm{mM} \mathrm{CaCl}_{2}$ (Buffer A) and eluted in same buffer lacking $\mathrm{CaCl}_{2}$ but supplemented with $10 \mathrm{mM}$ EDTA. This step was followed by a superose 6 size exclusion chromatography equilibrated in buffer A. Protein was concentrated to $9 \mathrm{mg} \mathrm{ml}^{-1}$ and dialysed three times against the deuterated buffer $25 \mathrm{mM}$ Tris DCl, $150 \mathrm{mM} \mathrm{NaCl}, 4 \mathrm{mM} \mathrm{CaCl}{ }_{2}$ at pD 7.8 in $\mathrm{D}_{2} \mathrm{O}$ (deuterated Trisd11 $(98 \%)$ was purchased from Cambridge Laboratories Inc. and the $\mathrm{D}_{2} \mathrm{O}$ from Spectra Stable Isotopes). Protein was then stored in liquid nitrogen.

\section{Acknowledgements}

We thank Fondo de Investigación Sanitaria (FIS) PI030093 (JR) for financial support. GT is supported by the CEA for his PhD appointment and FF thanks Bill and Melinda Gates foundation (pediatric dengue vaccine initiative) for funding support and NEC and JAP thanks MCyT (SAF 2003-08003-CO2) and MEC (SAF 2006-13391-CO3) for funding support.

\section{References}

1 Y.van Kooyk and T. B. Geijtenbeek, Nat. Rev. Immunol., 2003, 3, 697-709.

2 S. Pohlmann, F. Baribaud and R. W.Doms, Trends Immunol., 2001, 22, 643-646.

3 T. B. Geijtenbeek, D. S. Kwon, R. Torensma, S. J. van Vliet, G. C. van Duijnhoven, J. Middel, I. L. Cornelissen, H. S. Nottet, V. N. Kewalramani, D. R. Littman, C. G. Figdor and Y. van Kooyk, Cell, 2000, 100, 587-597.

4 G. Tabarani, J. J. Reina, C. Ebel, C. Vives, H. Lortat-Jacob, J. Rojo and F. Fieschi, FEBS Lett., 2006, 580, 2402-2408.

5 F. Halary, A. Amara, H. Lortat-Jacob, M. Messerle, T. Delaunay, C. Houles, F. Fieschi, F. Arenzana-Seisdedos, J. F. Moreau and J. ChanetMerville, Immunity, 2002, 17, 653-664.

6 P. Y.Lozach, H. Lortat-Jacob, L. A. de Lacroix, I. Staropoli, S. Foung, A. Amara, C. Houles, F. Fieschi, O. Schwartz, J. L. Virelizier, F. Arenzana-Seisdedos and R. Altmeyer, J. Biol. Chem., 2003, 278, 2035820366.

7 A. de Parseval, S. V.Su, J. H. Elder and B. Lee, J. Virol., 2004, 78, 2597-2600.

8 S. V.Su, P. Hong, S. Baik, O. A. Negrete, K. B. Gurney and B. Lee, J. Biol. Chem., 2004, 279, 19122-19132.

9 E. W. Adams, D. M. Ratner, H. R. Bokesch, J.B. McMahon, B. R. O'Keefe and P. H. Seeberger, Chem. Biol., 2004, 11, 875-881. 
10 E. van Liempt, C. M. C. Bank, P. Mehta, J. J. Garcia-Vallejo, Z. S. Kawar, R. Geyer, R. A. Alvarez, R. D. Cummings, Y.van Kooyk and I. van Die, FEBS Lett., 2006, 580,6123-6131.

11 S. Meyer, E. van Liempt, A. Imberty, Y. van Kooyk, H. Geyer, R. Geyer and I. van Die, J. Biol. Chem., 2005, 280, 37349-37359.

12 H. Feinberg, D. A. Mitchell, K. Drickamer and W. I. Weis, Science, 2001, 294, 2163-2166.

13 Y.Guo, H. Feinberg, E. Conroy, D. A. Mitchell, R. Alvarez, O. Blixt, M. E. Taylor, W. I. Weis and K. Drickamer, Nat. Struct. Mol. Biol., 2004, 11, 591-598.

14 H. Feinberg, R. Castelli, K. Drickamer, P. H. Seeberger and W. I. Weis, J. Biol. Chem., 2007, 282, 4202-4209.

15 J. J. Reina, S. Sattin, D. Invernizzi, S. Mari, L. Mart'ınez-Prats, G. Tabarani, F. Fieschi, R. Delgado, P. M. Nieto, J. Rojo and A. Bernardi, ChemMedChem, 2007, 2,1030-1036.

16 L. Tailleux, O. Schwartz, J. L. Herrmann, E. Pivert, M. Jackson, A Amara, Legres, D. Dreher, L. P.Nicod, J.C. Gluckman, P.H. Lagrange, B. Gicquel and O. Neyrolles, J. Exp. Med., 2003, 197, 121-127.

17 N. Maeda, J. Nigou, J. L. Herrmann, M. Jackson, A. Amara, P. H. Lagrange, G. Puzo, B. Gicquel and O. Neyrolles, J. Biol. Chem., 2003, 278, 5513-5516.

18 Y.van Kooyk, B. Appelmelk and T. B. Geijtenbeek, Trends Mol. Med., 2003, 9, 153-159.

19 E. A. Koppel, I. S. Ludwig, M. S. Hernandez, T. L. Lowary, R. R. Gadikota, A. B. Tuzikov, C. M. Vandenbroucke-Grauls, Y.van Kooyk, B. J. Appelmelk and T. B. Geijtenbeek, Immunobiology, 2004, 209, 117 127.

20 J. J. Reina and J. Rojo, Tetrahedron Lett., 2006, 47, 2475-2478.

21 J. R. Brisson and J.P. Carver, Biochemistry, 1983, 22, 1362-1368; R. J. Woods, A. Pathiaseril, M. R. Wormald, C. J. Edge and R. A. Dwek, Eur. J. Biochem., 1998, 258, 372-386; E. W. Sayers and J. H Prestegard, Biophys. J., 2000, 79, 3313-3329; M. Martin-Lomas, N. Khiar, S. Garcia, J. L. Koessler, P. M. Nieto and T. W. Rademacher, Chem.-Eur. J., 2000, 6, 3608-3621; L. Gonzalez, M. Bruix, T. DiazMaurino, T. Feizi, M. Rico, D. Solis and J. Jimenez-Barbero, Arch. Biochem. Biophys., 2000, 383, 17-27; A. Almond and J. U. Duus, J. Biomol. NMR, 2001, 20, 351-363; A. Almond, J. Bunkenborg, T. Franch, C. H. Gotfredsen and J. O. Duus, J. Am. Chem. Soc., 2001, 123, 4792-4802; L. M. Mikkelsen, M. J. Hernaiz, M. Martin-Pastor, T. Skrydstrup and J. Jimenez-Barbero, J. Am. Chem. Soc., 2002, 124, 14940-14951; E. W. Sayers and J. H. Prestegard, Biophys. J., 2002,82, 2683-2699; K. Lycknert, A. Helander, S. Oscarson, L. Kenne and G. Widmalm, Carbohydr. Res., 2004, 339, 1331-1338; S. Mari, H. Posteri, G. Marcou, D. Potenza, F. Micheli, F. J. Canada, J. Jimenez-Barbero and A. Bernardi, Eur. J. Org. Chem., 2004, 5119-5125; F. Chevalier, J. Lopez-Prados, P. Groves, S. Perez, M. Martin-Lomas and P. M. Nieto, Glycobiology, 2006, 16, 969-980; C. Clavel, A. Canales, G. Gupta, F. J. Canada, S. Penades, A. Surolia and J. Jimenez-Barbero,
Eur. J. Org. Chem., 2007, 1577-1585; C. Clavel, A. Canales, G. Gupta J. I. Santos, F. J. Canada, S. Penades, A. Surolia and J. Jimenez-Barbero, Glycoconjugate J., 2007, 24, 449-464; B. Hakkarainen, L. Kenne, M. Lahmann, S. Oscarson and C. Sandstrom, Magn. Reson. Chem., 2007, 45, 1076-1080.

22 M. Frank, T. Lutteke and C. W. von der Lieth, Nucleic Acids Res., 2007, 35, 287-290; http://www.cermav.cnrs.fr/glyco3d/index.php.

23 M. Mayer and B. Meyer, Angew. Chem., Int. Ed., 1999, 38, 1784-1788.

24 B. Meyer and T. Peters, Angew. Chem., Int. Ed., 2003, 42, 864-890; V. Jayalakshmi and N. R. Krishna, J. Magn. Reson., 2004, 168, 36-45; N. R. Krishna and V. Jayalakshmi, Prog. Nucl. Magn. Reson. Spectrosc., 2006, 49, 1-25.

25 J. Jimenez-Barbero and T. Peters, in NMR Spectroscopy of Glycoconjugates, ed. J. Jimenez-Barbero and T. Peters, Wiley-VCH, Weinheim, 2003 , ch. 12 , pp. 289-310.

26 SYBYL 7.0, Tripos Inc.,1699 South Hanley Rd., St.Louis, Missouri, 63144, USA. 2007.

27 W.D. Cornell, P. Cieplak, C. I. Bayly, I. R. Gould, K. M. Merz, D. M. Ferguson, D. C. Spellmeyer, T. Fox, J. W. Caldwell and P. A. Kollman, J. Am. Chem. Soc., 1995, 117, 5179-5197.

28 S. J. Weiner, P. A. Kollman, D. T. Nguyen and D. A. Case, J. Comput. Chem., 1986, 7, 230-252.

29 A. Imberty, E. Mikros, J. Koca, R. Mollicone, R. Oriol and S. Perez, Glycoconjugate J., 1995, 12, 331-349.

30 D. A. R. Sanders, D. N. Moothoo, J. Raftery, A. J. Howard, J. R. Helliwell and J. H. Naismith, J. Mol. Biol., 2001, 310, 875-884.

31 O. P. Judson and D. Haydon, J. Mol. Evol., 1999, 49,539-550.

32 P.Lavigne, J. R. Bagu, R. Boyko, L. Willard, C. F. B. Holmes and B. D. Sykes, Protein Sci., 2000, 9,252-264.

33 V. Sobolev, A. Sorokine, J. Prilusky, E. E. Abola and M. Edelman, Bioinformatics, 1999, 15, 327-332.

34 M. Brandl, M. S. Weiss, A. Jabs, J. Suhnel and R. Hilgenfeld, J. Mol. Biol., 2001, 307, 357-377.

35 A. Kerzmann, D. Neumann and O. Kohlbacher, J. Chem. Inf. Mod., 2006, 46, 1635-1642.

36 A. L. Davis, E. D. Laue, J. Keeler, D. Moskau and J. Lohman, J. Magn. Reson., 1991, 94, 637-644.

37 A. Bax and D. G. Davis, J. Magn. Reson., 1985, 65, 355-360.

38 R. Wagner and S. Berger, J. Magn. Reson., Ser. A, 1996, 123, 119-121.

39 A. A. Bothnerby, R. L. Stephens, J. M. Lee, C. D. Warren and R. W. Jeanloz, J. Am. Chem. Soc., 1984, 106, 811-813.

40 J. Schleucher, M. Schwendinger, M. Sattler, P. Schmidt, O. Schedletzky, S. J. Glaser, O. W. Sorensen and C. Griesinger, J. Biomol. NMR, 1994 4, 301-306.

41 D. Marion and K. Wuthrich, Biochem. Biophys. Res. Commun., 1983, 113, 967-974.

42 D. A. Mitchell, A. J. Fadden and K. Drickamer, J. Biol. Chem., 2001, 276, 28939-28945. 